NBER WORKING PAPER SERIES

\title{
EARNINGS DETERMINATION AND TAXES: \\ EVIDENCE FROM A COHORT BASED PAYROLL TAX REFORM IN GREECE
}

\author{
Emmanuel Saez \\ Manos Matsaganis \\ Panos Tsakloglou \\ Working Paper 15745 \\ http://www.nber.org/papers/w15745
}

\author{
NATIONAL BUREAU OF ECONOMIC RESEARCH \\ 1050 Massachusetts Avenue \\ Cambridge, MA 02138 \\ February 2010
}

We thank David Card, Raj Chetty, Peter Diamond, Arie Kapteyn, Bruce Meyer, and numerous seminar participants for helpful discussions and comments. We thank Christos Skiadas, Director of Acturial Studies and Statistics at IKA for giving us access to the administrative data and Giorgos Chelidonis at IKA for his help in preparing and advice on using the data. Financial support from NSF Grant SES-0850631 is gratefully acknowledged. The views expressed herein are those of the authors and do not necessarily reflect the views of the National Bureau of Economic Research.

NBER working papers are circulated for discussion and comment purposes. They have not been peerreviewed or been subject to the review by the NBER Board of Directors that accompanies official NBER publications.

(C) 2010 by Emmanuel Saez, Manos Matsaganis, and Panos Tsakloglou. All rights reserved. Short sections of text, not to exceed two paragraphs, may be quoted without explicit permission provided that full credit, including $\odot$ notice, is given to the source. 
Earnings Determination and Taxes: Evidence from a Cohort Based Payroll Tax Reform in

Greece

Emmanuel Saez, Manos Matsaganis, and Panos Tsakloglou

NBER Working Paper No. 15745

February 2010

JEL No. J23,J38

\section{ABSTRACT}

This paper analyzes the response of earnings to payroll tax rates using a cohort-based reform in Greece. All individuals who started working on or after 1993 face permanently a much higher earnings cap for payroll taxes, creating a large and permanent discontinuity in marginal payroll tax rates by date of entry in the labor force for upper earnings workers. Using full population administrative Social Security data and a Regression Discontinuity Design, we estimate the long-term incidence and effects of marginal payroll tax rates on earnings. Standard theory predicts that, in the long run, new regime workers should bear the entire burden of the payroll tax increase (relative to old regime workers). In contrast, we find that employers compensate new regime workers for the extra employer payroll taxes but not for the extra employee payroll taxes. We do not find any evidence of labor supply responses around the discontinuity, suggesting low efficiency costs of payroll taxes. The non-standard incidence results are the same across firms of different sizes. Tax incidence, however, is standard for older workers in the new regime as they bear both the employee and employer tax. Those results, combined with a direct small survey of employers, can be explained by social norms regarding seniority-based pay which create a growing wedge between pay and productivity as workers age.

Emmanuel Saez

Department of Economics

University of California, Berkeley

549 Evans Hall \#3880

Berkeley, CA 94720

and NBER

saez@econ.berkeley.edu

Manos Matsaganis

Athens University of Economics and Business

76 Patission Street

Athens 10434

Greece

matsaganis@aueb.gr
Panos Tsakloglou

Athens University of Economics and Business

76 Patission Street

Athens 10434

Greece

tsaklog@aueb.gr 


\section{Introduction}

In most OECD countries, social insurance programs such as public retirement benefits, public health insurance, disability and unemployment benefits, are financed by social security contributions on employment income. Such payroll taxes are quite large and impose significant marginal tax rates on earnings in countries with generous social insurance programs. Payroll taxes collect about $25 \%$ of total revenue on average in OECD countries (OECD, 2008), which is about the same as personal income taxes. Payroll taxes are much simpler than individual income taxes and share some key characteristics: (1) The base is in general restricted to employment earnings. (2) Tax rates are flat. ${ }^{1}$ (3) The tax often applies only to earnings below a given cap. ${ }^{2}$ (4) Payroll taxes are nominally shared by employers and employees. In a standard model, this nominal sharing does not matter for incidence and behavioral responses and, as a result, only the combined tax is relevant. To assess the efficiency and welfare consequences of such large payroll taxes, it is critical to estimate how labor supply and labor demand respond to them.

There is an extensive literature on the behavioral responses of reported income to the individual income tax (see Saez, Slemrod, and Giertz (2009) for a recent survey). Relative to the classic labor supply literature focusing on hours of work (see Blundell and MaCurdy (1999) for a survey), the new reported income literature recognizes that there are many other potential dimensions of responses such as unmeasured effort on the job, career choices, forms of compensation (non taxable fringe benefits, business vacations, etc.), and tax compliance. Those studies use individual income tax changes to estimate the elasticity of reported income with respect to marginal tax rates. There are two main issues with such elasticity estimates. First, non-tax related changes in the income distribution might be improperly attributed to changes in taxes when one compares a group affected by a tax change (such as high-income earners) to a comparison group not affected by a tax change (such as lower income earners). Second, tax changes can only credibly estimate short-term behavioral responses although long-term behavioral responses are of most interest for policy.

\footnotetext{
${ }^{1}$ Tax rates sometimes vary by occupation but tend to be flat for a given employee in a given occupation.

${ }^{2}$ Some countries apply different caps to different social contributions, creating tax rate variation by earnings levels. For example, the United States has caps for Social Security retirement and disability contributions but no cap for elderly health insurance Medicare contributions. Some countries such as the United Kingdom also have floors exempting the first slice of earnings from payroll taxes.
} 
In contrast, there is relatively little work on how payroll taxes affect labor supply. The literature on payroll taxes has focused primarily on incidence. In principle, as we expect labor demand to be substantially more elastic than labor supply, the incidence should be borne primarily by workers (Hamermesh, 1993). This has been the standard assumption in most analysis of the distributional effects of taxes (see e.g., Fullerton and Metcalf 2002 for a survey). ${ }^{3}$ Indeed, the most compelling macro-economic argument suggesting that the incidence is borne primarily by workers is the fact that the labor income share (which includes all payroll taxes) in GDP is fairly stable overtime and across countries (see e.g., OECD, 1990). A number of studies have used micro-data (either individual or at the industry level) and exploited payroll tax changes to analyze incidence effects and have found mixed results (Hamermesh 1979, Neubig 1981, Holmlund 1983, Gruber 1997, Anderson and Meyer, 1997, 2000, Lang 2003). Some studies have also tried to test whether the sharing of payroll taxes between employees and employers is irrelevant but have not reached a consensus on this question (Poterba et al. 1986, Dusek 2002, Mulligan, Gil, and Sala-i-Martin 2002). Importantly, those studies use standard payroll tax changes and hence suffer from the same two criticisms as the taxable income elasticity literature: identification is not fully compelling and the studies estimate short-run effects.

In this paper, we exploit an unusual payroll tax reform in Greece to estimate the long-run incidence and effects of taxes on earnings which overcomes identification difficulties that have plagued previous work. Greece has very high payroll tax rates on private sector workers with an employer tax rate of $28 \%$ and employee tax rate of $16 \%$ (on average), creating a combined marginal tax wedge of about $35 \%$ as a proportion of labor costs (gross earnings) Those payroll taxes apply up to a monthly earnings cap above which no marginal tax is charged. In late 1992, Greece introduced a reform in its payroll tax system to raise more revenue and restore the financial balance of its social insurance programs. The payroll tax change, however, applies only to new entrants, i.e., workers starting to work and pay payroll taxes on or after January 1st, 1993. Employees who started to work before 1993 continue to pay a combined employee and employer payroll tax up to a monthly cap equal to $€ 2315$ as of 2007 . In contrast, employees who started to work on or after 1993, pay the same payroll tax rates but up to a much higher

\footnotetext{
${ }^{3}$ This incidence assumption is also implicitly made in the reported income elasticity studies. A few studies have shown that this assumption does not necessarily hold in reality and that employers may share part of the burden. See Bingley and Lanot (2002) and Kubik (2004) for the income tax and Leigh (2010) and Rothstein (2009) for the US Earned Income Tax Credit.
} 
cap, equal to 2.3 times the old cap (€5280 of monthly earnings as of 2007). ${ }^{4}$ As a result, today, about $10 \%$ of workers who entered shortly before 1993 are above the cap and face no payroll taxes at the margin. In contrast, only about 1\% of workers who entered shortly after 1993 are above the new higher cap. Interestingly, this tax increase was not binding in the first years of the career as new entrants hardly ever had starting salaries above the old cap. However, as workers gain experience over the years, more and more reach the old cap level of earnings. Thus, the reform has effectively created two groups of workers who currently co-exist in the same labor market but face sharply different tax rates when they reach 2315 euros of monthly earnings (as of 2007).

Comparing pre-reform entrants to post-reform entrants using a regression discontinuity design (RDD) based on exact date of entry offers a unique opportunity to (a) evaluate the long-run incidence of employee and employer payroll taxes on earnings, (b) estimate the long-term impact of marginal tax rates on earnings. For this study, we have obtained access to administrative data from IKA, the social insurance agency in Greece, which manages payroll taxes and benefits for most private sector employees. The data include all individual workers in Greece who first entered the IKA system in any of the 10 years from 1988 to 1997. The data include the year of birth, gender, nationality, the exact day of entry in IKA (i.e., the first day with covered IKA earnings), and detailed job level and earnings variables for each of the months of March 2004, March 2005, March 2006, and March 2007. In each of those March datasets, and for each job, we have occupation, monthly earnings broken down into various types: regular earnings, overtime earnings, bonuses, and other forms of earnings. Besides overtime earnings, the data also include other measures of labor supply: monthly days of work, indicators for full day and full week work, which can be used to construct a standard measure of hours of work. Finally, the data include several employer level variables: industrial sector, geographical location, total number of employees in the firm. The longitudinal structure of the database allow us to link earnings and employers of each individual across time periods March 2004, March 2005, March 2006, and March 2007.

Four main results are presented in our analysis. First, we show that there is no discontinuity in the number and composition of workers around the cut-off date showing that individuals did not have time to game the law by rushing into the labor market in the last months of 1992 after

\footnotetext{
${ }^{4}$ Post-reform entrants had no cap at all on their payroll taxes from 1993 to 2003 . In 2004, a cap equal to 2.3 the old cap was introduced.
} 
the law was enacted and before 1993 to take advantage of the old regime.

Second and most important, we obtain non-standard incidence results. In principle, individuals entering shortly before 1993 and shortly after 1993 should be identical to employers and hence should receive the same gross earnings-as they are equally productive. However, we find that employers are willing to compensate new regime employees for their higher employer payroll taxes but not for their higher employee payroll taxes. As a result, new regime employees above the cap have (a) higher labor costs, i.e., gross earnings including all payroll taxes than old regime employers, (b) same posted earnings (the official measure of earnings which excludes employer payroll taxes but includes employee payroll taxes), (c) lower net earnings (when deducting all payroll taxes). Those results are true for total earnings (base pay + overtime + bonuses) but also for regular earnings (base pay).

Third, we find no evidence of effects of the payroll marginal tax rate differential on labor supply. Even if new regime workers bear only the employee portion of extra payroll taxes, this still reduces significantly (by 16\% on average) net earnings at the margin relative to old regime workers. However, we find no evidence that new regime workers work fewer days, are less likely to report overtime earnings, bonuses, or take-up more than one job. The elasticity of hours of work with respect to the net-of-tax rate that we estimate is very close to zero and insignificant, which implies low efficiency costs of payroll taxes.

Fourth, we find that the incidence is standard, i.e. employers shift the burden of employer payroll taxes on workers, for older workers (conditional on date of entry in IKA). However, there is no heterogeneity across firm's size. There is suggestive evidence that turnover is higher among new regime workers.

Finally, a survey of a few employers suggests that indeed employers do not try to reduce the earnings of new entrants in spite of the higher payroll taxes. In contrast to our prior views, employers say that fairness concerns about treating similar employees (old regime vs. new regime) differently in terms of earnings is not the primary reason for those results. Almost all employers report that young workers tend to be the most productive but are also those paid the least because of norms regarding seniority-based pay. As a result, in spite of higher taxes due to the new regime, those young workers remain profitable hires to employers. We speculate that norms of seniority-based pay increases force firms to increase the slope of the wage profile relative to marginal productivity profile. Those norms seem to be based on posted earnings (as 
opposed to labor costs or net earnings). Firms may not be able to deviate from those norms because doing so might negatively affect morale among employees or public relations and hence not be profitable in the long-run. Such norms could explain the non-standard incidence result we obtained, and the fact that incidence is closer to standard for older workers.

Our paper is organized as follows. Section 2 presents the institutional details of the Greek payroll tax and social insurance system, the administrative data we use for the analysis, and the standard conceptual framework. Section 3 presents our empirical results. Section 4 presents results from an employer survey and proposes a simple explanation accounting for the facts. Finally Section 5 offers a brief conclusion and discusses policy implications.

\section{Institutional Setting, Data, and Conceptual Frame- work}

\subsection{The Greek Payroll Tax System and the 1992 Reform}

Social benefits in Greece accounted in 2004 for $26.0 \%$ of GDP (compared to an average of $27.3 \%$ in the 25 countries who were European Union members in that year). As elsewhere in Europe, social benefits are mainly financed through payroll taxes, also called social contributions.

Social insurance in Greece is fragmented along occupational lines. IKA, the social insurance scheme for private sector employees, covers almost 2.0 million contributors, or $45 \%$ of all active workers. The rest are divided among OAEE, the own-account workers' scheme for the selfemployed with over 800,000 contributors, the farmers' scheme with 700,000 contributors, the civil servants' scheme with 450,000 contributors, as well as a number of special schemes covering specific professions such as doctor, lawyers, or engineers. This paper focuses exclusively on IKA workers. ${ }^{5}$

Social contributions payroll taxes for workers insured with IKA are set as proportion of monthly earnings as shown in Table 1 and are shared by employees and employers. Total contributions are quite high. Under the most common case (coverage code 101), the total employer rate is $28.06 \%$ of earnings and the total employee rate is $16 \%$ of earnings. ${ }^{6}$ Employer contribu-

\footnotetext{
${ }^{5}$ There are significant differences in social insurance arrangements across schemes, in terms of contribution rates and benefits. Typically, the special schemes enjoy much more favorable terms relative to IKA, OAEE, and the farmers' schemes.

${ }^{6}$ Workers in occupations classified as hazardous (about $40 \%$ of IKA contributors fall into that category) pay even higher rates.
} 
tions are calculated on top of posted earnings, while employee contributions as deductions from earnings. The same contribution rates apply to all earnings irrespective of type (e.g. regular pay, overtime, bonus, etc.) or contract (e.g. full-time or part-time). Social insurance contributions are payable from the first euro earned and are always deducted at source by employers.

Importantly, contributions are based on monthly earnings and apply only up to a cap, above which no payroll taxes apply. In 2007, the cap for employees under the old regime (i.e., those employees who have IKA covered earnings before January 1st, 1993), was set at $€ 2,315.00$ of monthly earnings in 2007. The cap for employees under the new regime (i.e., those employees who do not have IKA covered earnings before January 1st, 1993), the cap was set at $€ 5,279.57$. Both caps increase slightly each year, and by the same proportion, to reflect nominal increases in pay. The annual increases have been exactly 4\% from 2004 to 2007 (the period we study). There is no formal indexation and increases are legislated each year. Note that new regime workers had no cap at all from 1993 to 2003. A cap set equal to 2.28 times the old regime cap was first introduced for new regime workers in 2004.

The contributions cap applies to all earnings irrespective of type, i.e., it is calculated by adding together earnings from regular pay, overtime, bonus, etc. earned in a given month. In the case of employees working for multiple employers, the cap for employer payroll taxes is based on monthly earnings within a given employer while the cap for employee payroll taxes is based on the sum of earnings across all employers. In practice, employers withhold both employee and employer taxes from paychecks up to the monthly cap. Multi-employer workers can apply to IKA for a refund of their employee contributions (but not the corresponding employer contributions) paid in excess of the cap. ${ }^{7}$ In the case of part-time employees, in the sense of workers employed for fewer days than the regular number of working days in the month, the cap is calculated on a pro-rata basis but only for old regime workers. ${ }^{8}$

\section{- Interactions with the Income Tax}

Income taxes are based on annual income net of all social security contributions and follow a progressive schedule, with marginal rates ranging from $15 \%$ to $40 \%$ in 2007 . Income taxes are also withheld at source, final income taxes due are determined after the end of the financial year, when income returns are assessed taking into consideration tax relief and income from other

\footnotetext{
${ }^{7}$ Payroll taxes in the United States follow a similar rule, although US payroll taxes are based on annual earnings, instead of monthly earnings.

${ }^{8}$ For new regime workers, there is no pro-rating.
} 
sources. Importantly, the income tax schedule is the same for old and new regime workers. As a result, we do not incorporate income taxes in our analysis.

\section{- The 1992 Pension Reform Act}

In late 1992, Greece enacted the Pension Reform Act of 1992 (Law 2084/1992) to restore financial balance of the public retirement system. The reform affected contributions (payroll taxes) and retirement benefits on a cohort basis. As mentioned above, new insurees, defined as individuals who did not have any covered earnings before January 1st, 1993 are treated differently from old insurees, defined as individuals who had some covered earnings before January 1st, 1993. On the contribution side, as mentioned earlier, a higher upper earnings ceiling (or, until 2003, no upper ceiling at all) was put in place for new insurees, leading to higher payroll taxes for high earners. Social insurance contribution rates were increased for both new and old insurees (contribution rates are always the same for new and old insurees).

On the retirement benefit side, the law also changed the benefits computation for new insurees making the benefits formula for new insurees slightly less generous than for old insurees. In principle, this could create a lifetime wealth effect for new insurees (relative to old insurees) which could lead to higher labor supply for new insurees. For the relatively young workers we study in this paper, it is unlikely that this effect would be very large. ${ }^{9}$

However, and most important for our present analysis, retirement contributions can be considered almost as a pure tax for workers far from retirement both in the old and new regime. This is important because if benefits are linked to contributions in an actuarially fair way and if there are no credit constraints, then contributions would not be a tax. As a result, increased contributions would have no impact on the lifetime budget constraint and hence should not impact labor supply. For old regime workers, retirement benefits are based on the total number of insured days during the full career and the last five years of earnings. As a result, changes in the level of earnings at least five years before retirement do not affect retirement benefits. Therefore, for young and middle age old regime workers at least 5 years away from retirement, the retirement portion of social contributions is essentially a pure tax. ${ }^{10}$ For new regime workers,

\footnotetext{
${ }^{9}$ The discontinuity across cohorts in benefits could affect retirement age and individual savings. Hence, the sharp cohort based discontinuity created by the Greek reform could also be a useful "natural experiment" to analyze retirement and savings decisions to changes in social security benefits down the road.

${ }^{10}$ It is not exactly a pure tax, as supplying more labor when young could alter the full career path and lead to higher earnings when older. As we mentioned above, it seems very unlikely that young workers would be rational enough to take this effect into account when making their labor supply decisions.
} 
retirement benefits are based on the total number of insured days during the full career and the highest five years of earnings among the last ten years of earnings. As a result, changes in the level of earnings at least ten years before retirement do not affect retirement benefits. Therefore, for young and middle age new regime workers at least 10 years away from retirement, the retirement portion of social contributions is also essentially a pure tax. Because our analysis focuses on relatively young workers-those who entered the IKA system between 1988 and 1997, as we shall see-retirement contributions are effectively a pure tax.

All the other contributions which finance sickness, unemployment, and other benefits, create virtually no linkage between the levels of contributions and benefits and can also be considered as pure taxes. Therefore, in this study, we will always consider all payroll taxes as pure taxes.

\subsection{Administrative IKA Database}

The data we use is extracted from the IKA administrative database. The data extract includes all individual workers in Greece who first entered the IKA system in any of the 10 calendar years from 1988 to 1997. Hence our data spans 10 cohorts, 5 before the reform and 5 after the reform. The core data include the year of birth, gender, nationality, the exact day of entry in IKA (i.e., the first day with covered IKA earnings), and insurance regime (old vs. new). The core data also include the sum of total insured days as of the end of 2005, as well as total 2005 annual earnings (broken down into regular and additional earnings). The data include scrambled individual identifiers (defined as a transform of the actual social security number) to link individuals across datasets.

We also have detailed job level and earnings variables for each of the months of March 2004, March 2005, March 2006, and March 2007. In each of those March datasets, and for each job, we have the number of days of work, occupation, monthly earnings, as well as full day and full week indicators of labor supply. Individuals with more than one job during the month will have more than one job record. Individuals are identified by their (scrambled) individual identifiers. The monthly earnings are broken down into various types: regular earnings, overtime earnings, bonuses, and other forms of earnings. Earnings are reported in full with no cap. The data also include the exact employer and employee tax rates (which depend on the insurance code), as well as the exact amount of employer and employee payroll taxes paid out for the corresponding job. Finally, the data include several employer level variables: industrial sector, geographical 
location, total number of employees in the firm, as well as an employer (scrambled) identifier to link across databases. The longitudinal structure of the database allow us to link earnings and employers of each individual across the time periods March 2004, March 2005, March 2006, and March 2007.

For most of our analysis, we create data at the individual level. For individuals with multiple employers, we define the main employer as the employer for which regular earnings are highest.

We limit our sample to individuals with Greek nationality (95\% of workers in our sample are Greek nationals) because foreign citizens in our initial sample have very unbalanced dates of entry concentrated in the later period of our data as foreign workers are primarily immigrants from Eastern Europe.

Table 2 reports summary statistics, as of March 2007, for four groups of workers with positive IKA earnings in March 2007: (1) Those entering IKA from 1988 to 1992, i.e., old regime workers, (2) those entering IKA from 1993 to 1997, i.e., new regime workers, (3) those entering IKA from 1988 to 1992 with March 2007 earnings above $€ 2315$ (the old regime cap), (4) those entering IKA from 1993 to 1997 with March 2007 earnings above $€ 2315$ (the old regime cap). Several points are worth noting.

First, virtually all the old entrants are in the old regime as expected. About 95\% of new entrants are in the new regime. The number is not $100 \%$ because individuals who had covered earnings in any insurance scheme (not necessarily IKA) before 1993 qualify for the old regime. As we shall see, this does not invalidate the analysis as entering IKA after 1992 is still a very strong predictor of regime status and hence marginal payroll tax rates.

Second, about $9 \%$ of all workers have earnings above the old cap (€2315), while only about $1 \%$ of all workers have earnings above the new cap (€5280). As shown in the table, the fraction of workers above the old cap is higher for old entrants because old entrants are older and have longer work experience, and hence higher earnings. The same is true for the fraction of workers above the new cap.

Third, workers above the old cap are more likely to have bonuses, more likely to be male, more likely to work in larger companies, and less likely to have changed employers from March 2006 to March 2007. None of those of results are surprising.

Finally, the bottom rows of Table 2 show that new entrants face higher marginal payroll tax rates on average. The difference becomes especially large when looking at workers above the 
old cap. This is not surprising as old entrants above the old cap by definition should face no marginal payroll tax ${ }^{11}$ while most new entrants above the old cap are still below the new cap and hence face the full marginal payroll tax rates. As shown in the table, the difference in the total combined marginal tax rate between old and new entrants above the old cap is almost 25 percentage points.

\subsection{Conceptual Framework}

We will use three definitions of monthly earnings. First, gross earnings $z$ are defined as earnings inclusive of employee and employer payroll taxes. Gross earnings can be interpreted as the total labor cost that employers pay for a given individual. ${ }^{12}$ Second, posted earnings $w$ are defined as gross earnings net of employer payroll taxes. In Greece, as in most other countries, payroll taxes are based on monthly posted earnings $w$. Earnings include not only the regular wages and salaries but also overtime pay, bonuses, as well as pay in arrears. It is therefore a broad definition of cash employment income which is used as the reference for computing payroll taxes and is also the standard reference for employer-employee compensation negotiations and decisions. Third, net earnings $c$ are defined as earnings net of employee payroll taxes. This is the amount of disposable income (before individual income taxes however) that the worker actually receives. ${ }^{13}$

We denote by $\tau_{R}$ and $\tau_{E}$ the employer and employee (respectively) marginal payroll tax rates. As described above, those marginal tax rates apply up to a threshold of earnings $\bar{w}$, which we call the cap. We denote by $\bar{w}_{O}$ the cap in the old regime (for pre-1993 entrants) and by $\bar{w}_{N}$ the cap in the new regime (for those entering after January 1st, 1993). As of 2007, we have $\bar{w}_{O}=2,315$ and $\bar{w}_{N}=2.28 \cdot \bar{w}_{O}=5,280$.

As $c=\left(1-\tau_{E}\right) w=\left[\left(1-\tau_{E}\right) /\left(1+\tau_{R}\right)\right] z=\left[1-\left(\tau_{R}+\tau_{E}\right) /\left(1+\tau_{R}\right)\right] z$, the combination of employer and employee payroll taxes are equivalent to a combined tax rate $\tau=\left(\tau_{R}+\tau_{E}\right) /\left(1+\tau_{R}\right)$ up to a threshold of gross earnings $\bar{z}=\bar{w} \cdot\left(1+\tau_{E}\right)$. In Greece, the most common rates are

\footnotetext{
${ }^{11}$ The rates are not exactly zero because of workers with multiple employers.

${ }^{12}$ The total exact labor cost might be slightly higher if employers offer additional fringe benefits. However, because the social security system is generous, such fringe benefits are rare in Greece.

${ }^{13}$ As mentioned above, individual income taxes are withheld at source as well so that take-home pay is $c^{\prime}=c-T(c)$ where $T($.$) represents the withholding schedule for the income tax. Because the individual income$ tax applies uniformly across cohorts with no differentiation between old and new entrants, we do not need to incorporate the individual income tax in our analysis.
} 
$\tau_{R}=28 \%$ and $\tau_{E}=16 \%$ for a combined rate $\tau=34.4 \% .{ }^{14}$ We denote by $\bar{z}_{O}$ and $\bar{z}_{N}$ the old and new cap in terms of gross earnings. Similarly, we denote by $\bar{c}_{O}$ and $\bar{c}_{N}$ the old and new cap in terms of net earnings.

\section{- Fixed labor supply}

We start with a model with no labor supply responses where individuals differ by skill $n$. Under perfect competition and assuming a general production function which is a function of the each (fixed) supply of skill, gross earnings for a given skill should be equal to the marginal productivity of that skill. The distribution of marginal products across workers comes from the combination of the general production function and the fixed supply of each skill and is therefore independent of the payroll tax system.

Workers who entered shortly before Jan 1st, 1993 versus shortly after Jan 1st, 1993 should be very close substitutes in the labor market as they should have very similar characteristics in terms of age, gender, education, and work experience. Therefore, in a frictionless labor market, an employer maximizing profits should not be willing to pay more for a new regime worker than for an old regime worker with identical characteristics and hence identical marginal productivity. This implies that the tax differential between new regime and old regime workers should be borne entirely by workers: gross earnings should be the same for both types of workers. This implies that posted earnings should be lower for new regime workers above the old cap by the amount of the extra employer payroll taxes. Similarly, net earnings for new regime workers above the old cap should be lower by the amount of extra employer plus employee payroll taxes.

\section{- Variable labor supply}

The simplest extension of our initial model is to assume that labor supply responds to marginal incentives. This model can be formally obtained by assuming that the individual with skill $n$ maximize a utility function $u^{n}(c, z)$ where $c=z-T(z)$ is disposable income, $z$ is gross earnings, and $T(z)$ is total employer plus employee payroll taxes. The utility function $u^{n}$ is increasing in $c$ and decreasing in $z$ (as labor supply is costly). As depicted on Figure 1, a cap on payroll taxes effectively introduces a (concave) kink in the budget constraint set of the individual.

\footnotetext{
${ }^{14}$ There is variation in rates based on industry and occupation, primarily due to differences between hazardous vs. non hazardous occupations.
} 
Figure 1 plots the budget constraints under the new and old regimes in the standard $(z, c)$ diagram. The standard labor supply model makes three predictions about the effect of the reform on labor supply depending on gross earnings levels. (1) New regime workers with gross earnings below $\bar{z}_{O}$ are not affected by the regime change. (2) New regime workers with gross earnings between $\bar{z}_{O}$ and $\bar{z}_{N}$ experience an increase in marginal payroll tax rates from 0 to $\tau$ so that their net-of-tax rate decreases from one to $1-\tau$. This will create primarily a substitution effect which will reduce gross earnings. There is pure substitution effect at $z=\bar{z}_{O}$ and the income effect grows with $z$. (3) New regime workers with gross earnings above $\bar{z}_{N}$ experience a pure income effect with no change in net-of-tax rates. This income effect should lead to an increase in earnings, under the standard assumption that leisure is a normal good. Our data on 1988-1997 entrants shows that the bottom $90 \%$ earners are below $\bar{z}_{O}$ and hence not affected by the reform. Only a very small fraction of workers (the top percentile) are above the new cap $\bar{z}_{N}$.

Therefore, controlling for date of entry, the distribution of gross earnings (labor costs) for post-reform entrants should be identical to the distribution of gross earnings for pre-reform entrants below the old cap, i.e., in the bottom $90 \%$ or so of the distribution. Between the old and new cap, i.e., in the top $10 \%$ but excluding the top percentile, labor supply responses should reduce gross earnings of post-reform entrants (relative to pre-reform entrants). Above the new cap, i.e. in the top percentile, labor supply responses should increase gross earnings of post reform entrants. Therefore, empirically, we will examine how the distribution of gross earnings, posted earnings, and net earnings vary by date of entry.

Note finally that the reform might also generate responses along the extensive margin. The increase in taxes for new entrants after 1993 might induce some workers to pursue alternative careers outside the IKA covered sector such as becoming self-employed or even migrating for a foreign country. This extensive margin should reduce the fraction of high income earners among new regime workers (relative to old regime workers), which is a hypothesis we will test.

\section{Empirical Analysis}

\subsection{Estimation Design}

As the 1992 reform is based on date of entry in the insurance system, our empirical analysis will be based on comparing current labor market outcomes based on date of entry into the 
IKA system. The reform creates a sharp discontinuity by date of entry with January 1st, 1993 being the dividing line. Because earnings and other characteristics vary by date of entry, for example older entrants have higher earnings because of higher experience and seniority as shown in Table 2, we cannot directly compare old and new entrants. However, absent the 1992 reform, we should expect differences between old and new entrants to shrink as we compare entrants just before and just after the cut-off line. This feature leads naturally to a Regression Discontinuity Design (RDD). We will identify effects by running regressions of the form:

$$
Y_{i}=\alpha_{0}+\beta_{0} \cdot 1\left(t_{i} \geq 0\right)+\sum_{k=1}^{K} \alpha_{k} \cdot t_{i}^{k}+\sum_{k=1}^{K} \beta_{k} \cdot t_{i}^{k} \cdot 1\left(t_{i} \geq 0\right)+X_{i} \gamma+\varepsilon_{i}
$$

where $t_{i}$ is the entry date of individual $i$ normalized so that $t=0$ at the cut-off line of January 1st, 1993 and $X_{i}$ denotes a vector of additional control variables. The coefficient of interest capturing the effect of the discontinuity at $t=0$ is $\beta_{0}$ (as the polynomials in $t^{k}$ are zero at $t=0)$. Polynomials in $t$ are included to control in a flexible way for the effect of date of entry

$t$ on outcome $Y$. There are two main ways to assess robustness of the RDD results to the specification: (1) restrict the sample to a narrower window around the cut-off date, which we will do by limiting the sample to 1991-1994 entrants (instead of 1988-1997 entrants), (2) include higher order polynomials (the parameter $K$ ) in the regression specification. In some cases, we combine observations from all four waves of March 2004, March 2005, March 2006, March 2007 data in our regression. In that case, we always cluster standard errors at the individual worker level.

A simple way to illustrate the RDD is to plot average outcome $Y$ by date of entry month bins and draw the quadratic fit below and above the cut-off line. Because of strong seasonal effects in entry date (due to the annual periodicity of the job market), we shall see that graphs based on annual date of entry are often more useful than monthly graphs to uncover effects. The graphical evidence will then guide the formal regression analysis.

\subsection{First Stage and Identification Checks}

Panel A on Figure 2 plots the fraction of March 2007 workers in the new regime by month of entry in the IKA insurance scheme. Unsurprisingly, there is an enormous discontinuity as hardly any worker entering IKA before $1 / 1 / 1993$ is in the new regime and about $95 \%$ of workers entering IKA on or after 1/1/1993 are in the new regime. As mentioned above, the number is 
not $100 \%$ because post reform IKA entrants may have made contributions to another insurance scheme before 1993, in which case they qualify for the old regime. Panel B in Figure 2 plots the fraction of workers (as of March 2007) above the earnings cap (€2315 for old regime workers and $€ 5280$ for new regime workers). The graph shows indeed a sharp discontinuity at the cut-off date showing that the fraction above the cap drops from about $8 \%$ down to $2 \%$ exactly at the discontinuity, reflecting the fact that most post reform entrants are in the new regime with the much higher cap. The fraction above the cap decreases smoothly by date of entry both among the old and new entrants because average earnings increase with age and experience as we shall see. Figure 2 demonstrates that the cohort based reform does create a very strong first stage effect on the probability of facing payroll taxes at the margin.

As mentioned earlier, a key requirement for identification is that the workers entering just before and just after the cut-off dates are comparable. This identification requirement could be invalidated if some workers had strategically selected their date of entry in response to the reform. Therefore, Figure 3 plots the number of workers by month of entry. Panel A focuses on the sample of all IKA workers with positive earnings as of March 2007 while Panel B focuses of the narrower sample of all IKA workers with earnings above the old cap (€2315) in March 2007.

The graphs show large month to month variations in the number of entrants due in part to seasonality effects. Importantly, the quadratic fit curves show that there is no discontinuity in the number of entrants around the cut-off date. Specifically, we observe no spike in the number of entrants just before the cut-off date. This implies that individuals did not try to game the system by rushing into IKA covered jobs just after the law was passed in late 1992 and before January 1st, 1993 to benefit from the more advantageous old regime. There are three possible explanations for the absence of gaming effects. First, there was very little time between the time the law was enacted in late 1992 and January 1st, 1993. Second, formal IKA covered jobs cannot easily be found or created, ${ }^{15}$ especially since by late 1992 the Greek economy had dipped into recession. Third, the difference between the two regimes might not have loomed large for young workers as they are very far from retirement to care about changes in retirement benefits and, at the very start of their career, their earnings are almost always below the old cap making the difference in caps irrelevant for a number of years. The absence of gaming is critical for our

\footnotetext{
${ }^{15}$ In contrast to the United States, most part-time and low paid jobs for teenage workers in Greece are not in the covered sector and hence do not qualify workers for the old regime status.
} 
subsequent analysis as gaming could have created a discontinuity in the composition of workers just below and just above the cut-off, and hence could have invalidated the RDD estimation.

The fact that we do not observe a discontinuity in Panel B, among highly paid workers, suggests that highly educated workers with high pay expectancy did not respond to the reform along the extensive margin by choosing to move to other sectors of activity outside IKA such as the self-employed or even migrating to another country, a point to which we will come back later on.

Figure 4 provides further identification checks by ploting the fraction male (Panel A) and the average age (Panel B) by month of entry. The fraction male was slightly above $50 \%$ for the early entry years and falls to slightly below $50 \%$ in in the late entry years. Unsurprisingly, the average age falls by date of entry. Most importantly however, in both cases, the graphs show that there is no discontinuity at the cut-off line supporting our hypothesis that entrants just before and just after the cut-off date are comparable.

Those first stage effects and the absence of effects along those other dimensions are formally estimated in a regression framework and presented in Table 3. The table displays the coefficients (with standard errors in parentheses) from regressing various outcomes (listed in the left-hand-side column) on a dummy for entering IKA on or after $1 / 1 / 1993$. The sample includes all entrants with positive monthly earnings in March 2007. ${ }^{16}$ Each row focuses on a specific outcome. Each column corresponds to variations in the RDD specification. Column (1) estimates includes a linear entry date (normalized to 0 at $1 / 1 / 1993$ ) and a linear entry date interacted with the dummy for entering IKA after 1/1/1993. Column (2) uses the same controls as column (1) but limits the sample to those entering IKA from 1991 to 1994 . Column (3-5) use all 1988-1997 entrants but add successively Monthly dummies (col. 3), quadratic date trends (quadratic term and quadratic term interacted with the dummy for entering IKA after 1/1/1993), cubic date trends (cubic term and cubic term interacted with the dummy for entering IKA after 1/1/1993). Total MTR is the combined marginal payroll tax rate adding employee and employer payroll tax rates. The marginal tax rate is zero when the individual worker is above cap. Two points should be noted.

First, the first stage results in terms of (a) percent in new regime, (b) percent reaching the cap (of their respective regime), (c) average marginal tax rate (among all workers) all display a

\footnotetext{
${ }^{16}$ Results are very similar in the other March 2004, March 2005, or March 2006 samples and omitted for sake of space.
} 
very significant discontinuity that is very robust for the various specifications such as restricting the sample to 1991-1994 or the number of polynomials date of entry controls included in the regression. Those results confirm the graphical results from Figure 2 showing that the Greek payroll tax reform did generate a very strong first stage effect. Second and in contrast, none of the identification checks variables displays robustly significant results. A variable may sometimes be significant in one specification but the result is not robust to alternative specifications. Therefore, those regression results also confirms our previous graphical analysis showing that the 1992 reform does not create discontinuities in the composition of the workforce around the reform cut-off date. Based on those results, we now turn to the second stage effects on earnings outcomes.

\subsection{Effects on Earnings}

\subsubsection{Effects on Average Earnings above Old Cap}

We now turn to the earnings results. Motivated by our theoretical framework, we should expect to find the strongest effects on the distribution of earnings between the old cap and new cap. Therefore, perhaps the most natural measure to look at is average earnings above the old cap but capping earnings at the new cap. In the case of earnings, we therefore consider the variable $\min \left(w, \bar{w}_{N}\right)$ where $\bar{w}_{N}$ is the new cap. In the case of gross earnings, we consider the variable $\min \left(z, \bar{z}_{N}\right)$ where $\bar{z}_{N}=\bar{w}_{N} \cdot\left(1+\tau_{R}\right)$ is the new cap in gross earnings. Similarly, in the case of net earnings, we consider the variable $\min \left(c, \bar{c}_{N}\right)$ where $\bar{c}_{N}=\bar{w}_{N} \cdot\left(1-\tau_{E}\right)$. Average gross earnings (resp. earnings, net earnings) above the old cap but capping earnings at the new cap are therefore defined as $E\left[\min \left(z, \bar{z}_{N}\right) \mid z \geq \bar{z}_{O}\right],\left(\operatorname{resp} . E\left[\min \left(w, \bar{w}_{N}\right) \mid w \geq \bar{w}_{O}\right]\right.$, $\left.E\left[\min \left(c, \bar{c}_{N}\right) \mid c \geq \bar{c}_{O}\right]\right)$. Our theoretical prediction from the standard model is that, if there are no labor supply responses, there should be no discontinuity for $E\left[\min \left(z, \bar{z}_{N}\right) \mid z \geq \bar{z}_{O}\right]$ at the date of entry cut-off, and that $E\left[\min \left(w, \bar{w}_{N}\right) \mid w \geq \bar{w}_{O}\right]$ and $E\left[\min \left(c, \bar{c}_{N}\right) \mid c \geq \bar{c}_{O}\right]$ should fall at the date of entry cut-off because of the mechanical increase in payroll taxes. If there are labor supply responses, then $E\left[\min \left(z, \bar{z}_{N}\right) \mid z \geq \bar{z}_{O}\right]$ should fall at the date of entry cut-off (and $E\left[\min \left(w, \bar{w}_{N}\right) \mid w \geq \bar{w}_{O}\right]$ and $E\left[\min \left(c, \bar{c}_{N}\right) \mid c \geq \bar{c}_{O}\right]$ should fall even more).

Figure 5, Panel A displays average monthly gross earnings (capped at the new cap as discussed above) for workers with earnings above the old cap by month of entry into IKA. To increase the precision of our estimates, we have pooled together earnings data from March 
2004, March 2005, March 2006, and March 2007. We inflate earnings for earlier years by $4 \%$ per year so that caps align exactly across the 4 waves (as both the old and new cap were adjusted upward by $4 \%$ each year from 2004 to 2007 to account for nominal wage growth). The cloud of dots and especially the quadratic fit curves show a very clear upward discontinuity in gross earnings around the cut-off line. In contrast to the theoretical prediction, gross earnings jump up for new regime employees.

Panel B on Figure 5 shifts to plots by year of entry-instead of month of entry-to reduce the number of dots and the underlying noise in the time series. The annual plots visually confirm the findings of Panel A that gross earnings jump up around the cut-off entry date. Post-reform entrants receive higher gross earnings than pre-reform entrants. Note that by far the biggest jump in the annual series occurs from 1992 to 1993 as the series is fairly stable in all other years, providing compelling evidence that the change in tax regime had a positive impact on gross earnings among high earners affected by the tax reform.

Figure 6, Panel A, displays simultaneously average gross earnings (already displayed on Figure 5, Panel B), average posted earnings, and average net earnings (always capped at the new cap) for individuals with earnings above the old cap. Formally, each of those three statistics are defined as $E\left[\min \left(z, \bar{z}_{N}\right) \mid z \geq \bar{z}_{O}\right], E\left[\min \left(w, \bar{w}_{N}\right) \mid w \geq \bar{w}_{O}\right]$, and $E\left[\min \left(c, \bar{c}_{N}\right) \mid c \geq \bar{c}_{O}\right]$. As we saw earlier, gross earnings increase at the cut-off date. However, there is no visible discontinuity in posted earnings. Finally, net earnings display a clear drop at the cut-off date. For all three series, the graphical evidence appears pretty precise as series are stable and smooth, except at the cut-off date. Panel B offers a "placebo" test by considering average gross earnings, posted earnings, and net earnings for the sample of individuals with earnings above $€ 1500$ and capping gross earnings, posted earnings, and net earnings at the old caps $\bar{z}_{O}=\left(1+\tau_{E}\right) \cdot \bar{w}_{O}, \bar{w}_{O}=2315$, and $\bar{c}_{O}$ respectively. This is a placebo because, in principle, there should be no discontinuity effects as individuals below the old cap are not affected by the 1992 reform. Indeed, the graph confirms that there is no visible discontinuity at the cut-off date as all three series are smooth and stable over the full period including around the cut-off date.

The graphical evidence displayed on Figures 5 and 6 offers striking evidence of the key point we will make in this paper. In sharp contrast to the standard model we developed above and which predicts that new regime entrants should bear the full (employee plus employer) payroll tax differential, we find that employers compensate new regime entrants for the extra employer 
payroll taxes so that gross earnings are higher for new entrants and posted earnings are actually the same for new and old entrants. In contrast, employees seem to bear the full burden of the extra employee payroll taxes so that net earnings are lower for new entrants. All standard theoretical models predict that the division between employer and employee payroll taxes should not matter for the ultimate incidence of the payroll taxes between employees and employers. The unusual cohort based Greek reform offers clear evidence contradicting this clear-cut prediction of the standard model.

Table 4 presents the RDD estimates corresponding to the graphical evidence displayed on Figures 5 and 6 using the same five RDD specifications used in the earlier Table 3. Panel A focuses on total earnings (as in Figures 5 and 6) while Panel B focuses solely on regular earnings (i.e., base salary excluding overtime, bonuses, and other special payments). Panel C considers the "placebo" experiment (as in Figure 6, Panel B) using the sample of individuals with earnings above $€ 1500$ and capping gross earnings, earnings, and net earnings at the old caps $\bar{z}_{O}=\left(1+\tau_{E}\right) \cdot \bar{w}_{O}, \bar{w}_{O}=2315$, and $\bar{c}_{O}$ respectively.

The table confirms the graphical results. First, in all specifications, we find a positive and significant effect for gross earnings. Gross earnings jump by about $€ 100-140$ at the discontinuity and the coefficients are precisely estimated with large t-statistics. Second, we find a small and always insignificant result for posted earnings. Third, we find a negative and significant effect for net earnings. Net earnings jump down by about $€ 70-100$ at the discontinuity, with significant t-statistics is all specifications. Fourth, as shown on Panel B, the results are pretty similar when considering only regular earnings (base salary) instead of full earnings. This shows that the nonstandard result is primarily due to base salary determination rather than additional earnings (overtime, bonuses, etc.). Finally, the placebo regressions consistently deliver very small and almost always insignificant results. This successfully shows that there is no discontinuity in earnings policies (gross earnings, earnings, or net earnings) at the cut-off entry dates below the old cap. Those negative placebo results can be seen as an additional identification check suggesting that there is no composition effect among workers around the cut-off entry date. Taken together, Table 4 offers compelling confirmation of our earlier graphical results and show that, for new entrants, employers bear the incidence of the extra employer payroll tax but that employees bear the incidence of the extra employee payroll tax. 


\subsubsection{Effects on Fraction of Workers with High Earnings}

Instead of considering average earnings statistics, we now consider an alternative statistic, namely the fraction of workers with gross earnings, posted earnings, or net earnings above given fixed thresholds $z^{*}, w^{*}, c^{*}$. From our theoretical framework, we expect this fraction to be continuous at the cut-off date if $z^{*}$ is below the old cap. This fraction should be stable for gross earnings $z$, go down for $w$ and $c$ if $z^{*}$ (resp. $\left.w^{*}, c^{*}\right)$ is between the old and new caps and there are no labor supply responses. With labor supply responses, this fraction should also go down for gross earnings $z$.

Figure 7, Panel A displays, by year of entry in IKA, the fraction of workers with gross earnings, posted earnings, and net earnings above $z^{*}=3000 \cdot\left(1+\tau_{R}\right), w^{*}=3000$, and $c^{*}=$ $3000 \cdot\left(1-\tau_{E}\right)$ as of March 2007. The cut-off $€ 3000$ is chosen so as to fall in between the old and new caps. Unsurprisingly, the fraction of high earners is declining with date of entry as older entrants have more experience and hence higher earnings as we documented in Table 2. The striking finding however is that this declining pattern does not happen for gross earnings around the cut-off date: the fraction with high gross earnings is virtually the same in 1993 as in 1992. For posted earnings, the series are smoothly declining with no visible discontinuity. For net earnings, the decline is actually more pronounced from 1992 to 1993. Those findings are fully consistent with our previous findings showing that gross earnings (resp. posted earnings, net earnings) are actually higher (resp. the same, lower) for new entrants than for old entrants around the cut-off.

Panel B offers a placebo test by displaying the fraction of workers with gross earnings, posted earnings, and net earnings above $z^{*}=2000 \cdot\left(1+\tau_{R}\right)$, w $w^{*}=2000$, and $c^{*}=2000 \cdot\left(1-\tau_{E}\right)$ as of March 2007. The cut-off $€ 2000$ is chosen so as to fall below the old cap. In principle, there should be no effect because the regime change does not affect taxes below the old cap as we discussed earlier. In that case, the series indeed do not display any discontinuity in their downward trend by date of entry around the cut-off date, providing a successful placebo check.

Table 5 presents RDD estimates based on those alternative earnings outcomes. Panel A estimates are for total earnings while Panel B estimates are for regular earnings (defined as base pay excluding bonuses, overtime, and other special payments). Based on the extensive robustness analysis with respect to RDD specification presented in Table 3 and 4, in Table 5, 
we limit ourselves to 2 specifications corresponding to columns (1) and (2) in Table 4: all entrants with linear trend controls and 1991-1994 entrants only with linear trend controls. Columns (1) to (3) are estimated based on all entrants and columns (4) to (6) are estimated based on the sample of 1991-1994 entrants only. Columns (1) and (4) are for gross earnings, columns (2) and (5) for posted earnings, and columns (3) and (6) for net earnings. The table shows that other outcomes above the old cap, such as the fraction of individuals above 3000 Euros (or 5000 Euros) follows the same pattern as we obtained above: there is an upward discontinuity for gross earnings, no robust discontinuity for earnings, and a downward discontinuity for net earnings. As our graphical evidence showed, we find no effects in the placebo case where we consider the fraction of workers above 2000 Euros.

\subsubsection{Effects on earnings across subgroups}

\section{- Effects by Age at Entry}

Figure 8 focuses on heterogeneity by age at entry. Both panels display, by year of entry in IKA, the average monthly gross earnings, posted earnings, and net earnings, capped at the new cap, for all workers above the old cap (as in Figure 5). Panel A is for workers aged 27 or less when they entered IKA while Panel B is for workers aged over 27 when they entered IKA. The two panels display a striking heterogeneity in payroll tax incidence. Young workers display the same non-standard incidence results as the full sample: at the cut-off entry date, gross earnings jump up, posted earnings are stable, while net earnings jump down. In contrast, for older workers, gross earnings are stable at the discontinuity, posted earnings jump down, and net earnings jump down even more. Therefore, older workers display tax incidence results consistent with the standard model whereby employers do not compensate new regime workers for employer payroll taxes, and hence workers bear the full burden of both employee and employer payroll taxes.

Panel A of Table 6 confirms the graphical results. Table 6 is built exactly along the model

of Table 5. It shows effects for gross earnings, posted earnings, and net earnings for two RDD specifications (the full 1988-1997 sample and the restricted 1991-1994 sample both with linear controls in date of entry) across 6 columns. For older workers, gross earnings do not display any significant change at the discontinuity while earnings and especially net earnings fall discontinuously. Note that the estimates are not as precise as in the full sample because old 
workers constitute only about $15 \%$ of all workers. ${ }^{17}$

Those results suggest that employers are more likely to pass on older workers the extra cost of payroll taxes for highly paid new regime workers than for younger workers. Those age based estimates were carried out because of the findings we obtained from our informal survey of employers discussed in Section 4.1. Therefore, we will discuss at length the interpretation of those aged based results in Section 4 .

\section{- Effects by Gender}

We estimate incidence effects on total earnings by gender in Table 6, Panel B. The results show that the RDD effect on gross earnings, posted earnings, and net earnings are about the same for men and women, and display in both cases the same non-standard incidence effects that we have found in the full sample. Those results imply that the inability or unwillingness of employers to pass on new regime highly paid workers the extra cost of payroll taxes is equally present for men and women.

\section{- Effects by Size of Firms}

It is conceivable that small firms have less formal compensation policies and perhaps less Union pressure and hence more flexibility to adjust pay based on the specific situation of the employee, and in particular the tax regime of the employee. We present estimates by size of firms in Table 6, Panel C. The estimates are very close across small and large firms. Those results imply that the inability or unwillingness of employers to pass on new regime highly paid workers the extra cost of payroll taxes is equally present in large and small firms. ${ }^{18}$

\subsection{Other Effects: Labor Supply, Turnover, and Pay Increases}

\subsubsection{Labor Supply}

We discussed in Section 2.3 the expected effects of the reform on labor supply under a standard incidence scenario. Our empirical results show instead that incidence is non-standard because new regime workers bear only the employee portion of the extra payroll taxes. However, our results show that new regime workers still bear the cost of the employee portion of the payroll tax, which adds a marginal tax wedge of $16 \%$ for high income earners (as shown on Table 1).

\footnotetext{
${ }^{17}$ This explains why the full sample generates results very similar to young workers. The standard incidence results is concentrated primarily among the $15 \%$ oldest workers, explaining why we chose the 27 age cut-off.

${ }^{18}$ We have experimented with different cuts by size of firm. We find that incidence results are similar across all firm's sizes.
} 
Therefore, it is conceivable that the extra employee tax rate could affect labor supply decisions of new regime high income earners.

Our data allow us to study labor supply decisions along several dimensions: days of work per month, overtime, full day vs. part day, bonuses, and multiple jobs. Because the administrative data have such rich labor supply variables, we construct monthly hours of work as follows. In Greece, a full day implies eight hours of work. Part day would be anything below eight hours. As the most common part day is half day, we assume that part day corresponds to four hours of work. We assume that overtime corresponds to additional hours of work over and above the regular hours. We compute the hours of work corresponding to overtime by assuming that the hourly wage rate in overtime is the same as in regular time. Finally, we cap monthly hours of work at 300 per month (less than one percent of the sample hits this cap). Our measure of hours of work certainly has some measurement error but significant measurement error in hours is also present in self-reported survey data. More importantly, our measure of marginal tax rates which is relevant for labor supply estimation is not affected by the measurement error in hours as marginal tax rates are based on total earnings which have very little measurement error.

We select our sample as follows. First, we compute the daily regular earnings by dividing regular monthly earnings by the number of days of work in the month. Recall that regular earnings include only base pay and do not include bonuses, overtime, and other special payments. Second, we select workers with daily regular earnings above $€ 2500 / 25=100$. We select this cutoff because IKA assumes that full time workers have 25 insurance days per month. Therefore, those workers will be above the old cap by working the average number of days just with regular earnings, and hence there will be discontinuity in marginal tax rates for additional days, overtime, or bonuses. We also select a placebo group of medium earning workers with regular daily earnings between 1500/25 and 2000/25 Euros. Regular earnings put those workers below the old cap and therefore they face no discontinuity in marginal tax rates at the cut-off date $1 / 1 / 1993$.

Figure 9, Panel A displays the average number of monthly hours of work in the regular job among high earners (treatment group) and among medium earners (control group) that we just defined. For both groups, the number of hours of work displays a small downward trend by date of entry. Note that the scale is very compressed as most workers work a standard 200 hours 
(=25 days times 8 hours) per month. Most importantly, there is no discontinuity from 1992 to 1993 for either group, suggesting that high earners do not respond to the higher rates by cutting their number of hours of work, in spite of bearing the burden of the additional employee marginal payroll tax.

Figure 9, Panel B displays the fraction of workers with overtime among high earners (treatment group) and among medium earners (control group). Overtime is much more common among medium earners (about 20\%) than among high earners (5\%). Most important, however, there is no evidence of discontinuity from 1992 to 1993 suggesting that high earners do not respond to the higher employee tax rates by reducing overtime.

Table 7, Panel A provides regression estimates of labor supply effects. Table 7 is built exactly along the model of Table 4. It shows effects for various labor supply outcomes using five RDD specifications across 5 columns with different set of controls. The first two rows show indeed that there is no discontinuity is days in regular job and overtime at the cut-off dates: virtually all estimates are insignificant. Table 7, Panel A presents results for two additional outcomes: percent with bonus and percent with multiple jobs. Those two outcomes do not display any significant effect at the cut-off date showing that there is no labor supply response along the bonus $^{19}$ or multiple job decisions.

Finally, the bottom of Panel A focuses on the standard hours of work measure. Consistent with our graphical findings on Figure 9A, the first row shows no significant discontinuity in hours of work at the cut-off date (and the standard errors rule out effects larger than 2 hours relative to a base of 200 hours per month on average). The second row (in bold) estimates the elasticity of hours of work with respect to the net-of-employee payroll tax rate. We regress $\log$-hours on $\log \left(1-\tau_{E}\right)$ where $\tau_{E}$ is the marginal employee payroll tax rate, instrumenting $\log \left(1-\tau_{E}\right)$ with a dummy for entering IKA in 1993 or after, and using additional controls as in the other estimates. This specification is based on our previous finding that new regime workers bear only the employee portion of payroll taxes. The key identification assumption is that, absent the reform, workers on each side of the cut-off date would supply the same number of hours of work. All our elasticity estimates are insignificant and very close to zeros implying that hours of work do not respond to marginal tax rates.

Therefore, we are not able to detect any labor supply effects of higher employee marginal

\footnotetext{
${ }^{19}$ Labor supply affects bonuses paid for individual performance. In some cases however, bonuses are based on collective performance. Individual labor supply has only a minor impact on collective bonuses.
} 
payroll tax rates. Our results show that the labor supply of upper income earners (about the top decile) affected by the discontinuity is fairly inelastic to payroll tax rates, even in the long-run as the discontinuity has been in place since 1993 and we observe earnings from 2004 to 2007, more than 10 years later. Perhaps even more importantly, our results show there is not much earnings manipulation taking place to avoid taxes (such as having new regime workers paid with deferred compensation or perks on the job instead of cash) as earnings of upper earners do not display any discontinuity at the cut-off date. Those results suggest that the high payroll tax rates in Greece (as in most European countries) may not have very large efficiency costs on high income earners.

\subsubsection{Turnover}

We now use the longitudinal structure of the data to analyze turnover effects. We define year to year turnover as changing the main employer from March of year $t$ to March of year $t+1$, where the main employer is the employer paying regular earnings (the highest regular earnings when a worker has multiple regular employers in a given month).

Figure 10, Panel A, displays, by year of entry in IKA, the fraction of workers changing jobs from one year to the next for two groups of workers: (1) high earners (those with earnings above the old cap and hence who are affected by the reform and called the treatment group), (2) medium earners (those with earnings between $€ 1500$ Euros and the old cap and hence not affected by the reform and called the control group). The series display a fairly sharp upward discontinuity in the treatment group but not in the control group suggesting that the higher tax rates do lead to higher turnover. Panel B in Table 7 confirms that there is a significant 1-2 percentage point increase (from a base of 15-20\%) in turnover at the discontinuity although it should be pointed out that the estimates are not always statistically significant and hence not as clear and strong as the effects on earnings we uncovered earlier.

Because new regime workers receive the same earnings as old regime workers around the discontinuity, we suspect that higher turnover comes primarily from employers' decisions. Employers may prefer to lay off or let go of new regime workers first as new regime workers might generate a smaller surplus for the employer due to the extra taxes. This is also likely to happen if the employer does not observe regime status at the time of hiring. We will come back to those points in Section 4. Importantly, however, in the long-run, employer driven extra turnover 
should lead to smaller earnings for new regime workers. The fact that we do not observe a discontinuity in cross sectional earnings (Figures 6 and 7 and Tables 4 and 5) more than 10 years after the reform suggests that those turnover effects are not strong enough to affect earnings significantly.

\subsubsection{Pay Increases}

Finally, we turn to the analysis of year to year increases in monthly nominal regular earnings using also the longitudinal structure of the data. We use regular earnings as this corresponds to the base salary is much more stable from year to year than total earnings. Figure 10, Panel B displays, by year of entry in IKA, the fraction of workers experiencing a nominal regular earnings (resp. gross earnings, net earnings) increase the following year for workers with regular earnings above the old cap in base year. Panel B displays a clear downward discontinuity for gross earnings, no discontinuity for posted earnings, and an upward discontinuity for net earnings. In other words and relative to old regime workers, new regime workers are less likely to receive a gross regular earnings nominal raise, as likely to receive a regular posted earnings nominal raise, and more likely to receive a net regular earnings nominal raise. Panel $\mathrm{C}$ in Table 7 confirms those results across all RDD specifications.

Those results are fully consistent with our previous results and can be explained as follows. For a worker in the new regime and above the old cap (and below the new cap), no nominal posted earnings change implies no nominal gross earnings and net earnings change as employer and employee payroll taxes are proportional to earnings. In contrast, for a worker in the old regime, no nominal posted earnings change implies that (1) gross earnings are increasing as the old cap increases by $4 \%$ from year to year and hence employer payroll taxes increase correspondingly, ${ }^{20}(2)$ net earnings are decreasing as employee payroll taxes also increase correspondingly. Hence, if employers keep nominal posted earnings fixed from year to year for a fraction of their employees, the pattern from Figure 10, Panel B naturally arises. The important lesson from those results is that employers seem to base (nominal) pay increase decisions on posted earnings (not gross earnings or net earnings). ${ }^{21}$ As a result, the discontinuity in taxes at the cut-off date generates a discontinuity in gross and net earnings but not for earnings. Those results are

\footnotetext{
${ }^{20}$ This is strictly true if nominal posted earnings are above the old cap in year $t+1$, equal to 1.04 the old cap in year $t$.

${ }^{21}$ Collective agreements in Greece always set pay rates in terms of posted earnings (Matsaganis, 2007 ).
} 
entirely consistent with our initial incidence results on earnings.

\section{Interpretation}

\subsection{Evidence from a Survey of Employers}

To understand the mechanism behind our non-standard incidence results, we carried out a small informal survey of five managers involved in personnel decisions at firms of medium to large size. Those managers were talking and providing perspective on behalf of employers, and hence we will refer to them as "employers". We also interviewed one union manager specializing on social security issues. Each of those six interviewees was asked a set of questions on knowledge of employers about the new vs. old tax regime and regime status of prospective recruits. Then we asked whether tax status matters to employers when making recruitment decisions and salaries offers, when offering pay raises to existing employees, or for lay-off decisions. If told that regime status does not affect those personnel decisions, we asked managers why this is the case. The exact formulation of the questions is provided in annex I to the paper.

Four important findings emerge from this survey. First, all five employers knew about the tax differential between old and new entrants but only two out of five said that they knew or asked this information for potential recruits.

Second and related, none of the five employers said that being in the new regime negatively affected hiring decisions, salaries offered, or subsequent pay raises or lay-off decisions. As one employer said “An employee's social insurance regime does not even come to mind when recruitment, pay, promotion or dismissal decisions are pondered within the firm." This is consistent with our empirical results showing that salaries (i.e., posted earnings $w$ ) are the same for old and new regime workers. This also explains why only two employers mentioned asking/knowing about tax regime when making recruiting decisions. In the end, regime status does not seem like a relevant parameter when making recruiting or compensation decisions.

Only one manager said "Discrimination against new regime workers at the time of recruitment may arise in theory when two candidates for a job not only are equally qualified but have similar age too. Clearly, such cases are exceptional."

Third, when we asked why regime status was not relevant for recruiting and compensation decisions, none of the three reasons we proposed in the questionnaire was seen as very relevant. 
None of the employers said that Union pressure to offer equal salary was relevant. This could be explained by the fact that Unionization rates in the private sector in Greece are low, around 15\% (Matsaganis, 2007) and Unions are even less relevant for highly paid workers above the old cap for whom the regime change is relevant. As one employer put it: "Since unions are rather weak in the private sector, wage setting (especially of highly-qualified workers) typically results from individual agreements and not collective bargaining. The deals struck are usually expressed in terms of salary [not gross earnings including employer payroll taxes]. Therefore, any difference in social contributions due to the higher cap of "new insurees" is absorbed by the firm." None of the employers said that fear of legal anti-discrimination action was a factor. One manager said 'Fear of litigation cannot explain firms' decisions, since younger workers are often less aware of their rights and more likely to be bullied by employers into accepting less favorable terms." The Union manager told us that he was not aware of any action on the part of the two union confederations he is advising, in defence of younger workers discriminated against by employers by virtue of their new regime status. Finally, only one employer said that fairness and morale concerns could explain the equal treatment of new and old regime employees, but even that point was made as a general statement against any form of discrimination: "Any kind of discrimination is against company policy. Moreover, it would definitely harm morale at the firm."

Fourth and perhaps most important, three of the five employers volunteered the following explanation, which we did not propose, for the absence of discrimination. Younger workers are often the most productive workers and yet are paid less because of pay seniority practices. As a result, young workers are valuable to companies, and that remains the case, even when factoring in the extra taxes due to the new regime. One manager said "Younger workers are not only not discriminated against, they are generally preferred because productivity is higher." Another volunteered "The importance of seniority in wage setting and pay rise decisions is such that in actual fact younger workers tend to be paid less for the same work than older ones, even though younger workers are more costly to the firm in terms of payroll costs compared to older workers at the same level of take-home pay." Finally, one employer mentioned "Since seniority and/or previous experience (and, sometimes, age) are the main determinants of pay, younger workers are by definition paid less. This compensates for the possibility of higher social contributions because of the cap." The Union manager also mentioned "If anything, it may be 
older workers that are discriminated against [in hiring and firing decisions]: on the one hand, because of seniority they are often paid better - while on the other hand, because of fatigue, they perform less well." This pay seniority explanation stating that old workers are overpaid while young workers are underpaid (relative to productivity) is consistent with our empirical finding from Figure 8: employers are willing to compensate young new regime for the extra employer payroll taxes but are not willing to compensate older new regime workers for whom we have found classical incidence.

\subsection{An Explanation: Social Norms Regarding Seniority-Based Pay}

The general finding that emerges from the informal survey is that employers do not behave as in the standard model and do not attempt to systematically pass on to new regime workers the tax differential. This is indeed consistent with our empirical results. Most importantly, the survey shows that employers face constraints in their profit maximization behavior that are not incorporated in the standard model where gross earnings are equated to marginal product. The survey strongly suggests that the critical constraint is seniority-based pay practices which require employers to offer pay profiles increasing with seniority even though actual productivity may actually fall with seniority.

There is a large empirical literature in labor economics analyzing whether wage profiles are steeper than productivity profiles (see Skirbekk (2004) for a recent survey). The key difficulty in this literature is to measure productivity independently of the wage. The general finding is that productivity follows an inverted U-shape over a working life while wages tend to increase continually with age. As a result, younger workers tend to be underpaid while older workers are over paid relative to productivity, a phenomenon sometimes called the tenure effect. Various studies have documented such a discrepancy between productivity and pay in various European countries (see e.g., Haegeland and Klette, 1999 for Norway, Crépon et al. 2002 for France, Ilmakunnas et al. 2004 for Finland). Interestingly, earlier studies suggest that such a discrepancy existed in the United States three decades ago (see e.g., Medoff and Abraham, 1980) but seems

to have largely disappeared by the 1990s (Hellerstein, Neumark and Troske, 1999). Conceivably, the more competitive the labor market, the smaller the tenure effect.

Theoretically, two broad types of explanations have been proposed for this tenure effect. First, the contract theory literature has proposed various models of long-term wage contracts 
when there is asymmetric information about workers productivity. Deferred wages could be a screening mechanism to encourage workers to join the firm for the long-term (Salop and Salop 1976). Deferred wages may deter shirking by raising the costs to a worker of being fired (Lazear, 1981). Finally, deferred wages can be desirable when workers are more risk averse than employers (Harris and Holmstrom 1982). Second, the behavioral economics literature has shown that individuals enjoy increasing pay profiles relative to flat or declining profiles with the same present discounted value (see e.g., Frederick, Loewenstein, and O'Donohue, 2002, and Clark, Frijters, and Shields, 2008 for recent surveys). In the case of the labor market and using direct survey evidence, Loewenstein and Sicherman (1991) and Frank and Hutchens (1993) show that workers prefer increasing wage profiles than flat or declining profiles with higher present discounted value. Increasing wage profiles might be valuable as a forced saving mechanism (when individuals have self-control problems) or because individuals inherently value the feeling of getting ahead. Our empirical results and employer survey evidence cannot be easily reconciled with the contract theory models. Indeed, any of those rational models would imply that the payroll tax differential should be fully reflected in the long-term contract and hence be borne entirely by workers. Similarly, the forced saving model would not generate the non-standard incidence we have uncovered.

A pure fairness model, where workers would not tolerate differences in earnings due solely to regime status would explain our incidence results in a partial equilibrium model, as it would constrain employers to offer equal earnings to identical workers just below and just above the cut-off entry date. However, such a non-standard incidence could not be sustained in general equilibrium as employers would try to avoid recruiting new regime workers, or would try to lay them off in priority, which would generate a discontinuity in earnings around the cut-off date in equilibrium. Such a model also seems inconsistent with the informal survey of employers. A model where employers do not observe regime status when they make hiring decisions would generate exactly the same predictions as the pure fairness model both in partial and general equilibrium, and hence cannot account for our empirical results either.

To obtain the non-standard incidence results, we propose an explanation based on social norms regarding seniority-based pay. A social norm reflects the preferences of society. It can influence profit maximizing businesses through additional constraints on behavior and such norms are often also supported by specific legislation or by institutions such as Unions. Let us 
assume that there is a social norm that employers need to pay older or tenured workers more, and that such seniority-based pay norms are based on posted earnings, i.e., posted salary net-of employer payroll taxes but inclusive of employee payroll taxes (and individual income taxes). This social norm arises perhaps because workers enjoy the feeling of getting pay rises and might be enforced partly by Union agreements which require firms to offer pay raises with seniority. Firms which do not offer such an increasing pay profile may not be able to hire workers in the first place, or might get into costly conflicts with their workers. Therefore, it is in the best interest of employers to respect the seniority-based pay norm.

In principle, a profit maximizing firm would want to arbitrage such a norm by hiring young workers, who are paid less than their marginal product, and laying-off older or tenured workers, who are paid more than their marginal product. Therefore, there must be additional constraints preventing firms from laying-off older workers: those constraints can be severance payments based on tenure. As one manager in our survey pointed out: "Labor shedding is typically done by "wastage" (i.e. retirement or voluntary departure) rather than by dismissal. Severance pay is a function of seniority, which means that workers who have been longer with the firm are less likely to be made redundant, as that would be too costly [to the firm]." Such a constraint may be another social norm: a firm laying-off workers with longer tenure might get into a conflict with its workforce.

In such a context, hiring a young worker is profitable to the firm, even if the young worker is in the new regime. As a result, firms will always want to hire young workers, regardless of regime status, when a vacancy arises. In equilibrium, it must be the case that young workers are fully employed so that it is difficult for firms to find young workers. Of course, if choosing between two identical young workers with different status, the firm prefers the old regime worker but those cases are rare as the social norms constraints effectively create rationing of young workers in the labor market. The salary (i.e., posted earnings $w$ ) of young workers is therefore binding at the social norm constraint, and as a result, for new regime workers, the incidence of extra employer payroll taxes is borne by employers while the incidence of extra employee payroll taxes is borne by employees. This model would also explain why employers are not willing to bear the burden of extra taxes for older new regime workers as those older workers may not be underpaid to start with. 


\section{Conclusions}

Using a unique cohort based reform of payroll taxes in Greece, our paper has uncovered compelling evidence of non-standard long-run tax incidence. We have found that employers bear the burden of the employer portion of payroll taxes while employees bear the burden of the employee portion of payroll taxes. In addition, we do not find any evidence of labor supply responses to the higher employee marginal payroll tax rate paid and borne by new regime workers. The informal survey of employers confirms that employers do not try to pass on employees the extra cost of employer payroll taxes. The view from employers is that the productivity of young high-skilled workers (who are paid above the old cap) is higher than their wages so that it remains profitable to hire young high-skilled workers in spite of the higher tax costs due to the tax reform. We have argued that such a reasoning cannot hold in a standard competitive labor market or even a fully rational contract theory model of the labor market. The most plausible explanation seems to be the existence of seniority-based pay social norms based on posted salaries (as opposed to either labor costs or net earnings) which impose constraints on firms' maximizing behavior. Those norms create a wedge between pay and productivity, and can explain our empirical findings, and in particular the fact that incidence reverts to standard for older workers.

It will be particularly interesting to follow up this cohort based reform in coming decades as our findings suggest that the non-standard incidence should progressively disappear with the aging of workers just above and just below the cut-off. If this ends up being the case, the reform will allow to estimate precisely the long-run labor supply effects of marginal payroll tax rates as new and old regime workers around the discontinuity will be facing sharply different earnings incentives at the margin. Our original interest in this Greek reform was precisely to use it to compellingly estimate long-run responses to marginal tax rates. The discovery of non-standard incidence made this original goal harder to reach but casts new interesting light on the workings of the labor market and pay determination.

The existence of such seniority-based pay norms raise interesting public policy issues. If older workers are paid more than their productivity, firms have incentives to either lay them off in priority or avoid hiring them, which can lead to high unemployment rates among older workers, a serious issue indeed in many European countries. The response of governments and unions has been to introduce firing costs laws, often in the form of severance payments, which 
grow with tenure, to reduce lay-offs among older workers, or to offer early retirement benefits. However, firing costs might exacerbate the difficulty of older workers in finding jobs in the first place, and early retirement benefits are very costly to government finances. Many public pension benefits formulas are based on the last years of earnings (instead of full career earnings). This also creates an incentive for firms and workers to tilt wages profiles to increase pension benefits at the expense of government finances.

Based on our evidence, a better government policy response might be to implement employer payroll tax deductions for older workers. If social norms are based on posted earnings (not including employer payroll taxes), such payroll tax reductions will be absorbed entirely by employers with no change in posted earnings for older workers. Indeed, Spain implemented such a reform in 2002 and Alvaredo and Saez (2010) show that the incidence fell entirely on employers, in contrast to the standard model, but in accordance with the seniority-based pay social norm model we have proposed. Another potentially valuable policy would be to change pension benefits formulas so as to base benefits not only on the last years of earnings but the full career, possibly by giving even more weight to early career earnings relative to late career earnings. We leave for future work the analysis of the optimal design of payroll taxes and retirement programs in the presence of social norms regarding pay seniority. 


\section{References}

Alvaredo, Facundo and Emmanuel Saez (2010). "The Effects of Payroll Taxes on Earnings: Evidence from Spanish Administrative Earnings Data." UC Berkeley Working Paper (in preparation).

Anderson, Patricia and Bruce D.Meyer (1997) "The Effects of Firm Specific Taxes and Government Mandates with an Application to the US Unemployment Insurance Program," Journal of Public Economics 65 (2), 119145.

Anderson, Patricia and Bruce D.Meyer (2000) "The Effects of the Unemployment Insurance Payroll Tax on Wages, Employment, Claims and Denials," Journal of Public Economics 78 (1-2), 81106.

Bingley, Paul and Gauthier Lanot (2002) "The Incidence of Income Tax on Wages and Labour Supply," Journal of Public Economics 83 (2), 173194.

Blundell, Richard and Thomas MaCurdy (1999). "Labor Supply: A Review of Alternative Approaches." In: Ashenfelter, O., Card, D. (Eds.), Handbook of Labor Economics, Volume 3A, North-Holland, Amsterdam.

Clark, Andrew E., Paul Frijters, and Michael A. Shields (2008) "Relative Income, Happiness, and Utility: An Explanation for the Easterlin Paradox and Other Puzzles", Journal of Economic Literature 46(1), 95-144.

Crépon, B., N. Deniau and S. Perez-Duarte (2002) "Wages, Productivity and Worker Characteristics: A French Perspective," Mimeo, INSEE.

Dusek, Libor (2002), "Visibility of taxes and the size of government", Working Paper.

Frank, Robert H., and Hutchens, Robert M. (1993) "Wages, Seniority, and the Demand for Rising Consumption Profiles.", Journal of Economic Behavior and Organization 21, 25176.

Frederick, Shane, George Loewenstein, and Ted O'donoghue (2002) "Time Discounting and Time Preference: A Critical Review," Journal of Economic Literature 40(2), 351-401.

Fullerton, Don and Gilbert Metcalf (2002). "Tax Incidence" In Auerbach A. and M. Feldstein (Eds.), Handbook of Public Economics, Volume 4, North-Holland, Amsterdam.

Gruber, Jonathan (1997) "The Incidence of Payroll Taxation: Evidence from Chile," Journal of Labor Economics 15 (3, Part 2), July 1997, S72-S101.

Haegeland, Torbjorn, and Klette, Tor Jacob. (1999) "Do Higher Wages Reflect Higher Productivity? Education, Gender and Experience Premiums in a Matched Plant- Worker Data Set." In The Creation and Analysis of Employer-Employee Matched Data, edited by J. Haltiwanger, J. Lane, J. R. Spletzer, J. Theeuwes, and K. Troske, Amsterdam: North Holland, 1999.

Hamermesh, Daniel S. (1979) "New Estimates of the Incidence of the Payroll Tax" Southern Economic Journal 45(4), 1208-1219.

Hamermesh, Daniel S. (1993) Labor Demand Princeton University Press: New Jersey.

Harris, Milton, and Holmstrom, Bengt. (1982) "A Theory of Wage Dynamics." Review 
of Economic Studies 49, 31533.

Hellerstein, Judith K., Neumark, David, and Troske, Kenneth R. (1999) "Wages, Productivity, and Worker Characteristics: Evidence from Plant-Level Production Functions and Wage Equations." Journal of Labor Economics 17, 409446.

Holmlund, Bertil (1983) "Payroll Taxes and Wage Inflation: The Swedish Experience." Scandinavian Journal of Economics 85, 115.

Ilmakunnas, Pekka, Maliranta, Mika, and Vainiomaki, Jari. (2004) "The Roles of Employer and Employee Characteristics for Plant Productivity." Journal of Productivity Analysis 21(4), 249-276.

Kubik, Jeffrey (2004) "The Incidence of Personal Income Taxation: Evidence from the Tax Reform Act of 1986," Journal of Public Economics 88 (7-8): 1567-1588.

Lang, Kevin 2003. "The Incidence of the Payroll Tax: A Test of Competing Models of Wage Determination". Working paper, Boston University.

Lazear, Edward P. (1981) "Agency, Earnings Profiles, Productivity, and Hours Restrictions." American Economic Review 71, 606-620.

Leigh, Andrew. (2010) "Who Benefits from the Earned Income Tax Credit? Incidence Among Recipients, Coworkers and Firms," forthcoming in B.E. Journal of Economic Analysis E Policy. Loewenstein, George and Nachum Sicherman (1991) "Do Workers Prefer Increasing Wage Profiles?" Journal of Labor Economics 9(1), 67-84.

Matsaganis Manos (2007) "Union structures and pension outcomes in Greece." British Journal of Industrial Relations 45(3), 537-555.

Medoff, James L. and Abraham, Katherine G. (1980) "Experience, Performance, and Earnings." Quarterly Journal of Economics 95, 70336.

Mulligan, Casey B., Ricard Gil, and Xavier Sala-i-Martin (2002), "Social Security and Democracy", NBER Working Paper No. 8958, May 2002, forthcoming B.E. Journal of Economic Analysis 8 Policy.

Neubig, Thomas (1981) "The Social Security Payroll Tax Effect on Wage Growth," Proceedings of the National Tax Association, 196-201.

OECD (1990), Employment Outlook, 1990, Organization for Economic Co-operation and Development: Paris.

OECD (2008) Revenue Statistics 1965-2007, Organization for Economic Co-operation and Development: Paris.

Poterba, James M, Julio J. Rotemberg, and Lawrence H. Summers (1986), "A TaxBased Test for Nominal Rigidities" American Economic Review 76(4), 659-675.

Rothstein, Jesse (2009) "Is the EITC as Good as an NIT? Conditional Cash Transfers and Tax Incidence," forthcoming American Economic Journal: Economic Policy.

Saez, Emmanuel, Slemrod, Joel and Seth Giertz (2009), "The Elasticity of Taxable Income with Respect to Marginal Tax Rates: A Critical Review", NBER Working Paper No. 15012, in preparation for the Journal of Economic Literature. 
Salop, Joanne and Steven Salop (1976) "Self-Selection and Turnover in the Labor Market," Quarterly Journal of Economics 90(4), 619-627.

Skirbekk, Vegard (2004): "Age and Individual Productivity: A Literature Survey", Vienna Yearbook of Population Research, Verlag der Osterreichischen Akademie der Wissenschaften, Vienna. 


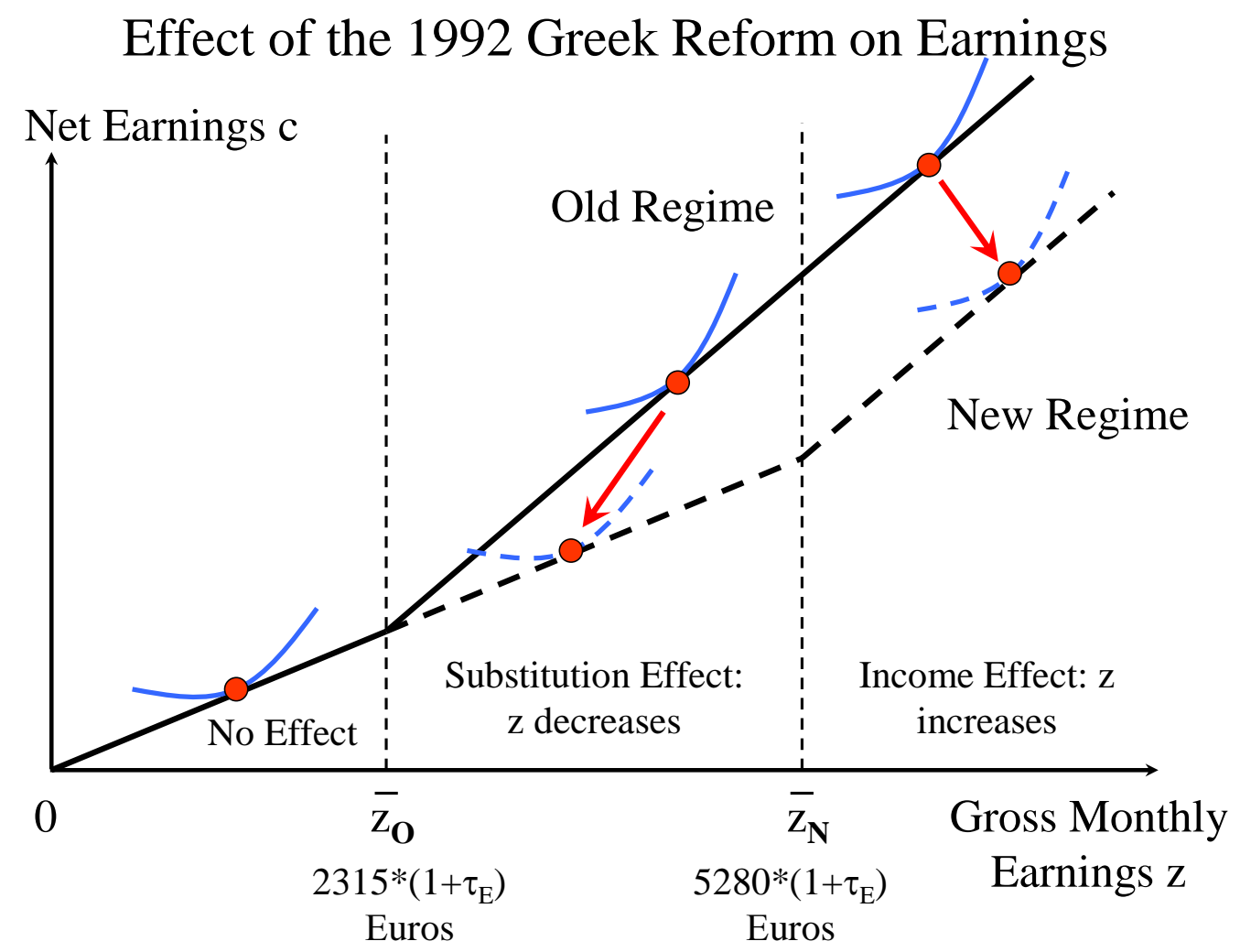

\section{Figure 1. Conceptual Framework}

The figure displays the effects of the 1992 pension reform in Greece on the monthly budget constraint of private sector employees (covered by the IKA social insurance system). The $\mathrm{x}$-axis represents monthly gross earnings (including both employer and employee payroll taxes). The y-axis represents monthly net earnings (earnings net of both employer and employee payroll taxes). The solid line is the old regime budget (for those entering the IKA system before 1993) and the dashed line is the new regime budget (for those entering the IKA system on or after 1993). The reform increased the cap in earnings subject to payroll taxes from $\mathrm{z}_{\mathrm{O}}$ to $\mathrm{z}_{\mathrm{N}}$ for new regime workers, hence shifting outward the kink point in the budget set where the payroll marginal tax rate ends. In the standard model, workers with monthly earnings below $\mathrm{z}_{\mathrm{O}}$ are unaffected by the reform. Workers with earnings between $z_{O}$ and $z_{N}$ experience a substitution effect which decreases gross earnings (and also an income effect but small relative to substitution effects). Workers with earnings above $\mathrm{z}_{\mathrm{N}}$ experience only an income effect which increases gross earnings. 

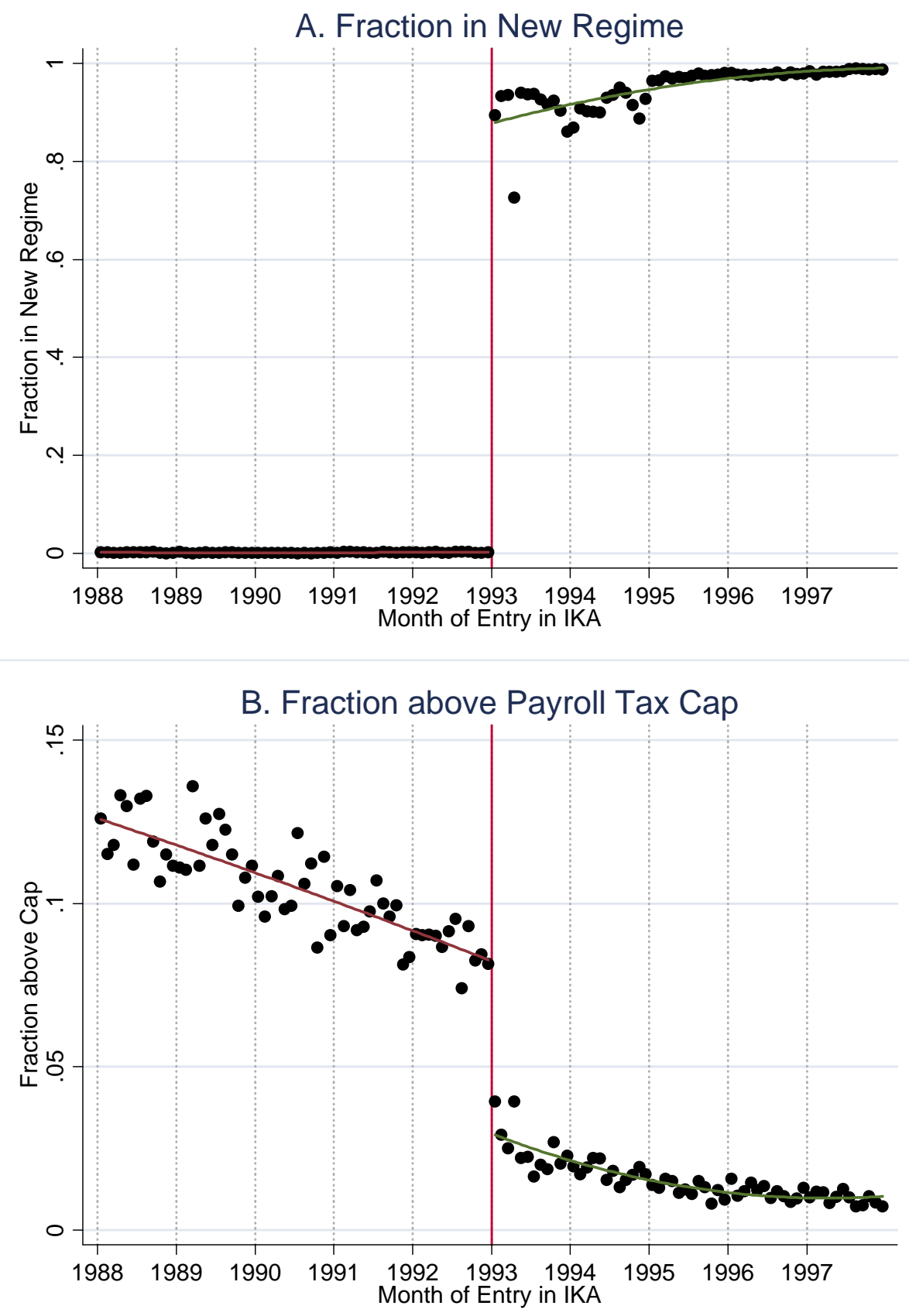

Figure 2. First Stage: Fraction in New Regime and above Cap by month of entry

In both panels, the sample is all workers with positive earnings in the IKA social insurance scheme as of March 2007. Panel A displays the fraction of workers in the new regime by month of entry into the IKA system. Workers entering IKA before 1993 are all in the old regime. The vast majority of workers entering IKA on or after 1993 are in the new regime. Some post-1993 entrants are in old regime because workers who had covered earnings before 1993 in any other social insurance scheme (outside IKA) still qualify for the old regime. Panel B displays the fraction of workers with earnings above the payroll tax cap. There is a sharp drop at the 1/1/1993 cut-off date as the cap for new regime workers is 2.28 times higher than for old regime workers. In both panels, the curve on each side of the discontinuity is the best quadratic fit. 

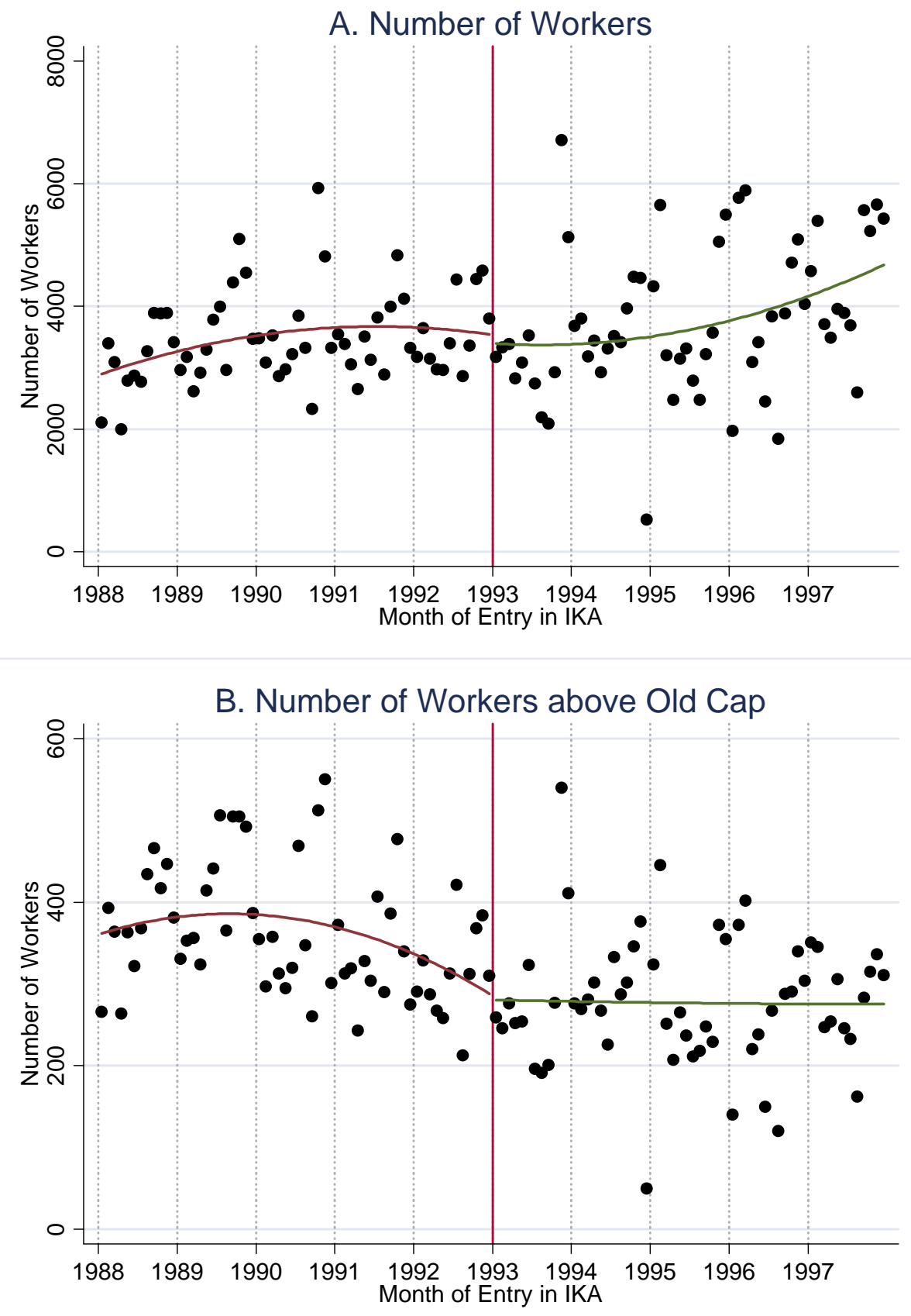

Figure 3. Identification Checks: Number of Entrants by Month of Entry

Panel A displays the number of workers by month of entry in the sample of workers with positive earnings as of March 2007. Panel B displays the number of workers by month of entry in the sample of workers with earnings above the old cap (2315 Euros) in March 2007. In both panels, the curve on each side of the discontinuity is the best quadratic fit. Both graphs display no discontinuity at the cut-off date showing that workers did not game the system by entering IKA before 1993 when the reform was enacted in late 1992 . Panel $\mathrm{B}$ also shows that highly skilled workers in the new regime did not respond to the higher tax along the extensive margin, by dropping out of IKA by migrating to jobs not covered by IKA. 

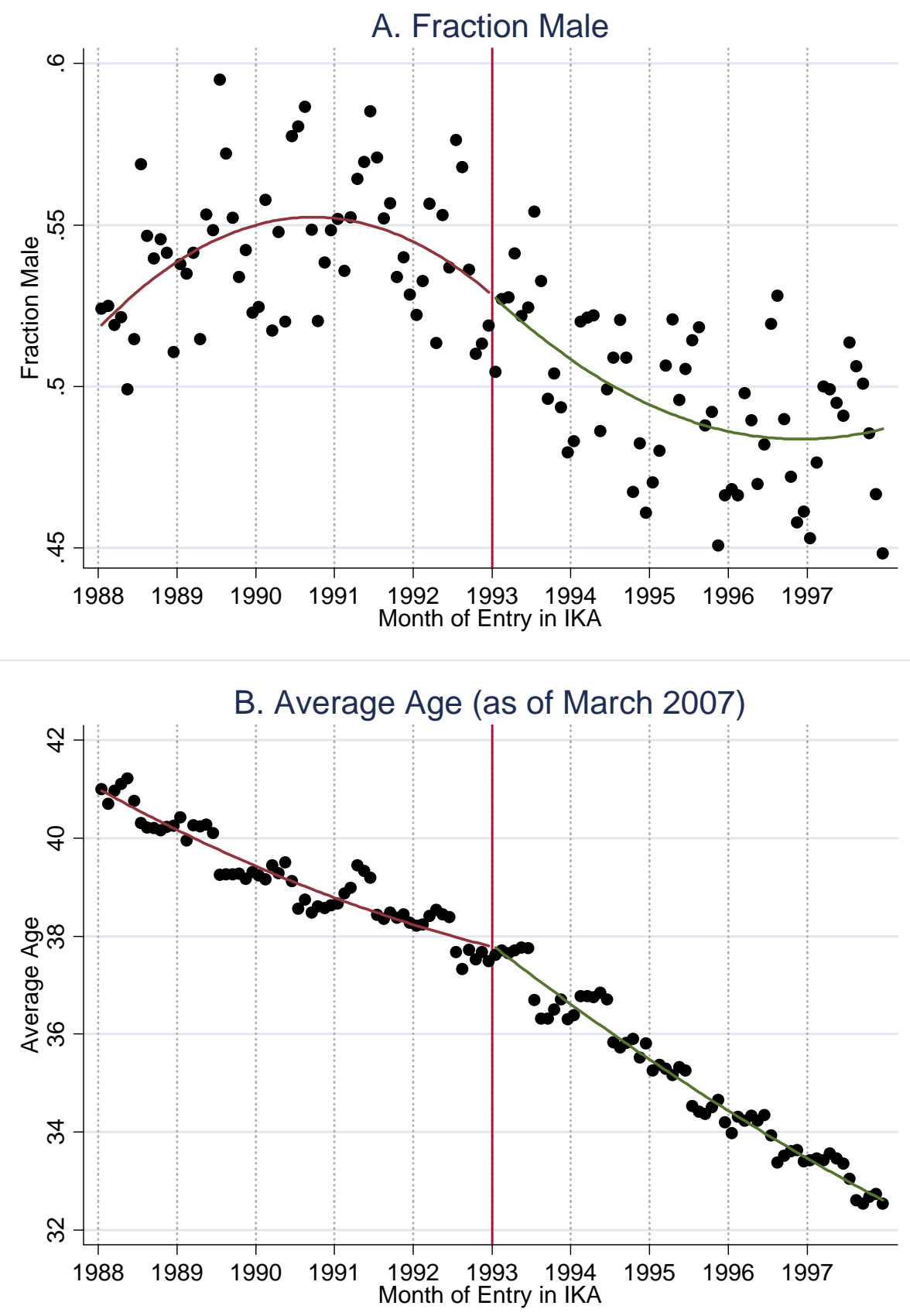

\section{Figure 4. Further Identification Checks: Gender and Age Composition}

In both panels, the sample is all workers with positive earnings in the IKA social insurance scheme as of March 2007. Panel A displays the fraction of male workers by month of entry in IKA. Panel B displays the age of workers (as of March 2007) by month of entry in IKA. In both panels, the curve on each side of the discontinuity is the best quadratic fit. Both graphs display no discontinuity at the cut-off date showing that there is no systematic difference in observable variables between entrants just above and just below the cutoff, a requirement for the Regression Discontinuity Design to be valid. Note the strong seasonality effects for age my month of entry. 

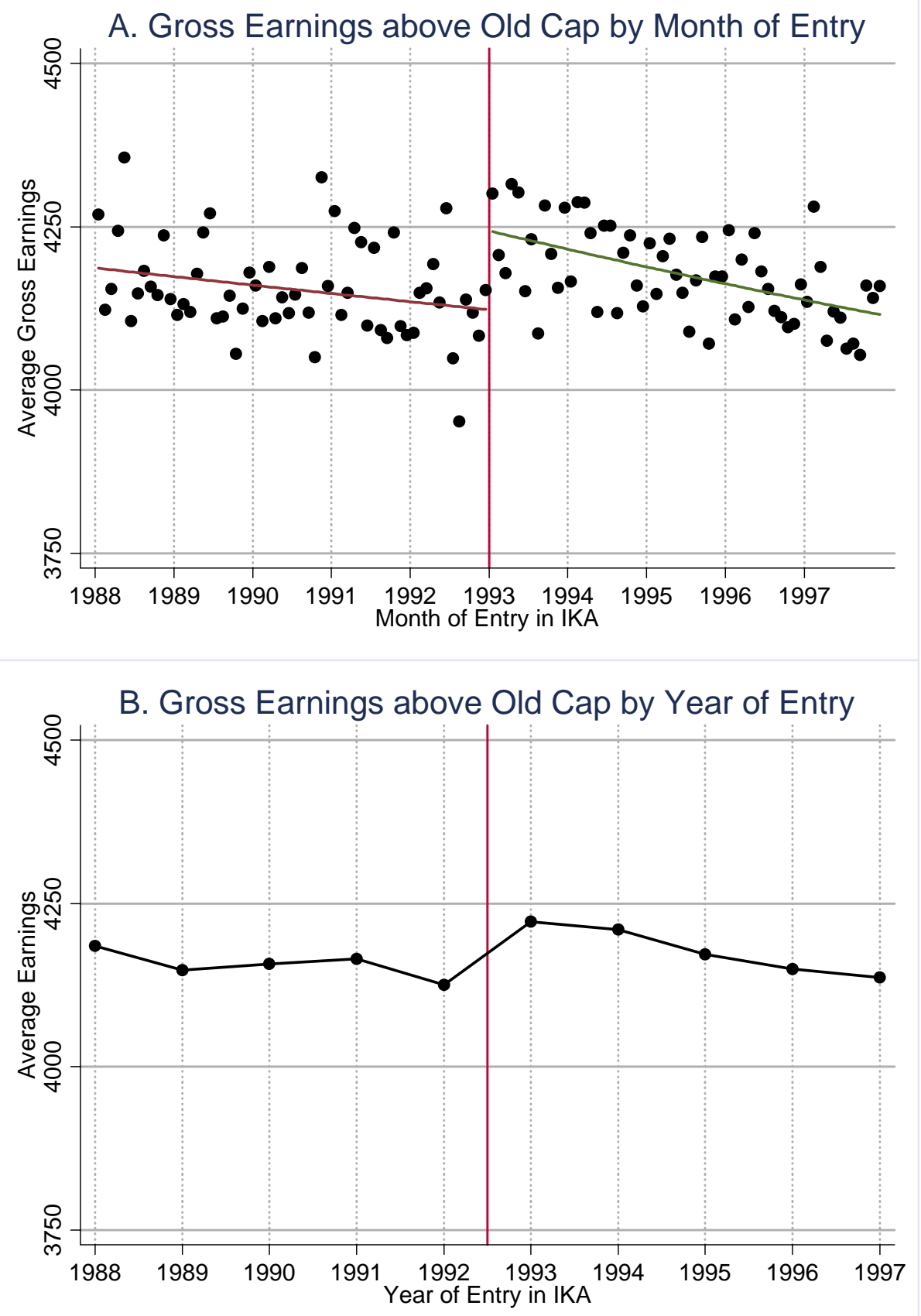

\section{Figure 5. Effects on Gross Earnings above Old Cap}

Panel A displays, by month of entry in IKA, the average monthly gross earnings $\mathrm{z}$, capped at the new cap $\mathrm{z}_{\mathrm{N}}$, for all workers with gross earnings above the old cap $\mathrm{z}_{\mathrm{O}}$. Formally, the statistic is defined as $\mathrm{E}\left(\min \left(\mathrm{z}, \mathrm{z}_{\mathrm{N}}\right) \mid \mathrm{z}>\mathrm{z}_{\mathrm{O}}\right)$. The series combine earnings records for March 2004, March 2005, March 2006, and March 2007. Earnings are adjusted by $4 \%$ per year by so that cap levels are aligned. The curve on each side of the discontinuity is the best quadratic fit. Panel B repeats the same series but aggregated by year of entry. Both panels show a clear upward discontinuity around the cut-off date, which goes opposite to the prediction from the standard model presented on Figure 1. 

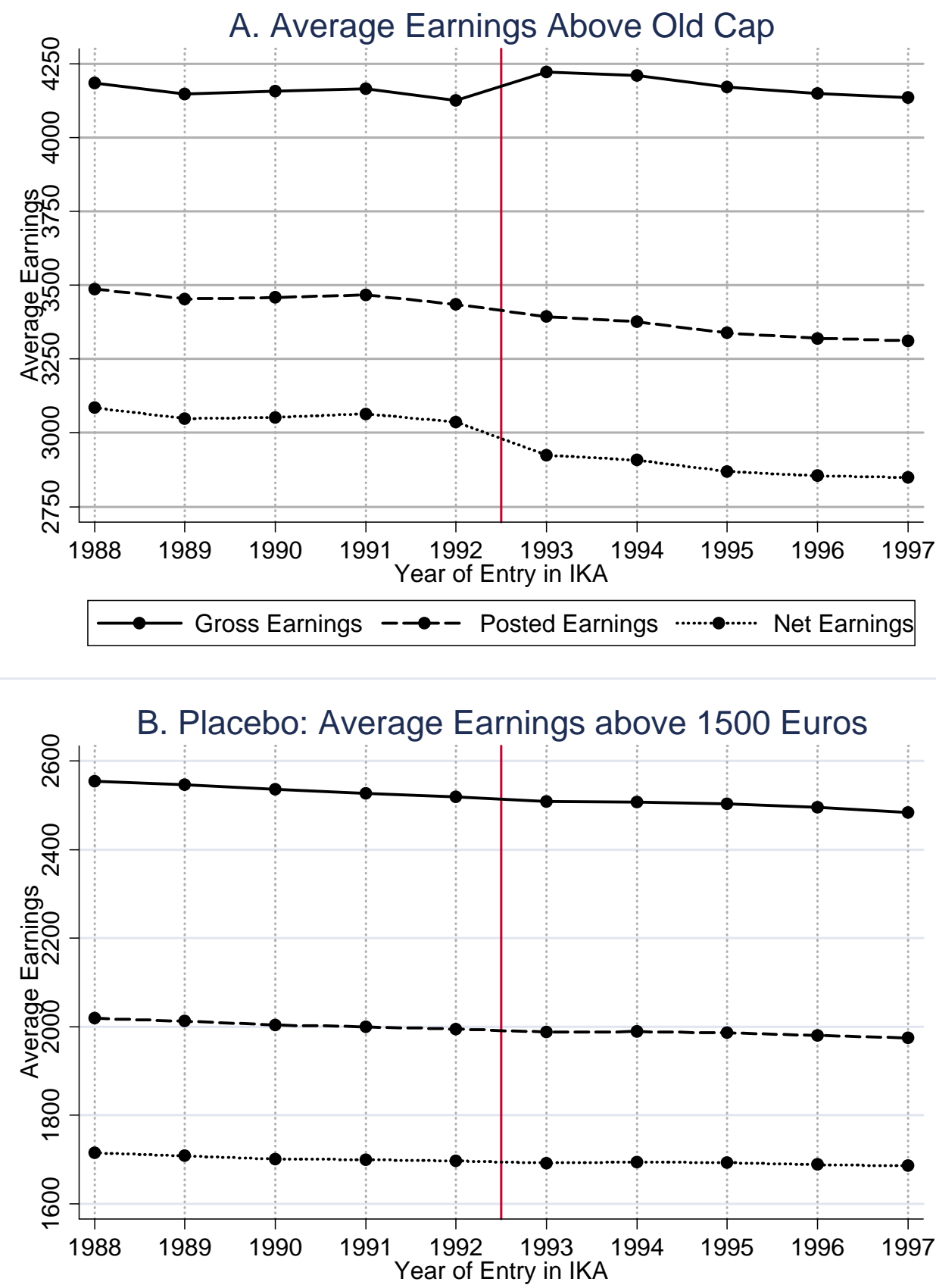

$\longrightarrow$ Gross Earnings $\quad \longrightarrow--$ Posted Earnings ….......... Net Earnings

Figure 6. Effects on Gross Earnings, Earnings, and Net Earnings above Old Cap

Panel A displays, by year of entry in IKA, the average gross earnings, posted earnings, and net earnings, capped at the new cap, for all workers above the old cap. Formally, the three statistics are defined as $\mathrm{E}\left(\min \left(\mathrm{z}, \mathrm{z}_{\mathrm{N}}\right) \mid \mathrm{z}>\mathrm{z}_{\mathrm{O}}\right), \mathrm{E}\left(\min \left(\mathrm{w}_{\mathrm{w}} \mathrm{w}_{\mathrm{N}}\right) \mid \mathrm{w}>\mathrm{w}_{\mathrm{O}}\right), \mathrm{E}\left(\min \left(\mathrm{c}, \mathrm{c}_{\mathrm{N}}\right) \mid \mathrm{c}>\mathrm{c}_{\mathrm{O}}\right)$. The graph shows that gross earnings jump up (relative to trend) at the cut-off date, posted earnings are continuous, and net earnings jump down, consistent with Figure 5. Panel B offers a placebo test by repeating the same series but average earnings capped at the old cap for all workers above 1500 Euros. In principle, such statistics should not be affected by the reform and indeed the graph confirms that there are no discontinuities in any of the three series at the cut-off date. Both panels combine earnings records for March 2004, March 2005, March 2006, and March 2007. 


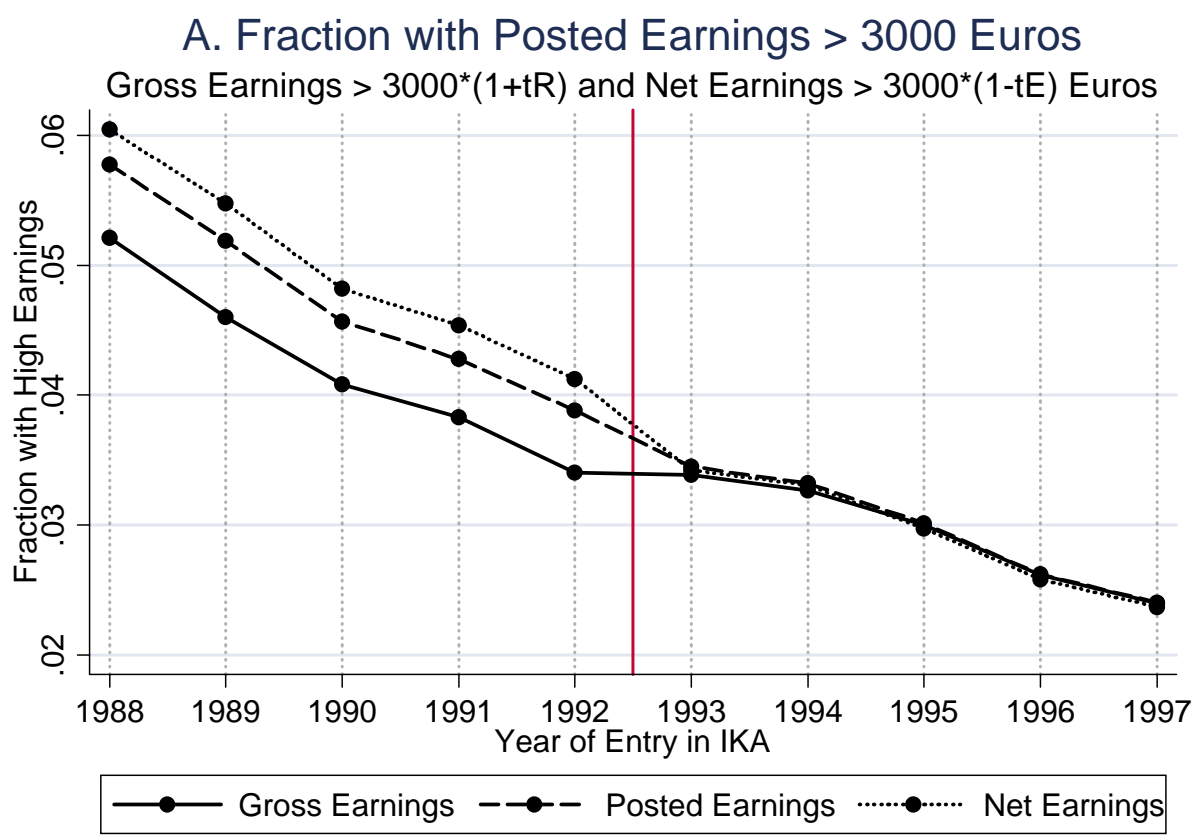

\section{B. Placebo: Fraction with Posted Earnings $>2000$ Euros}

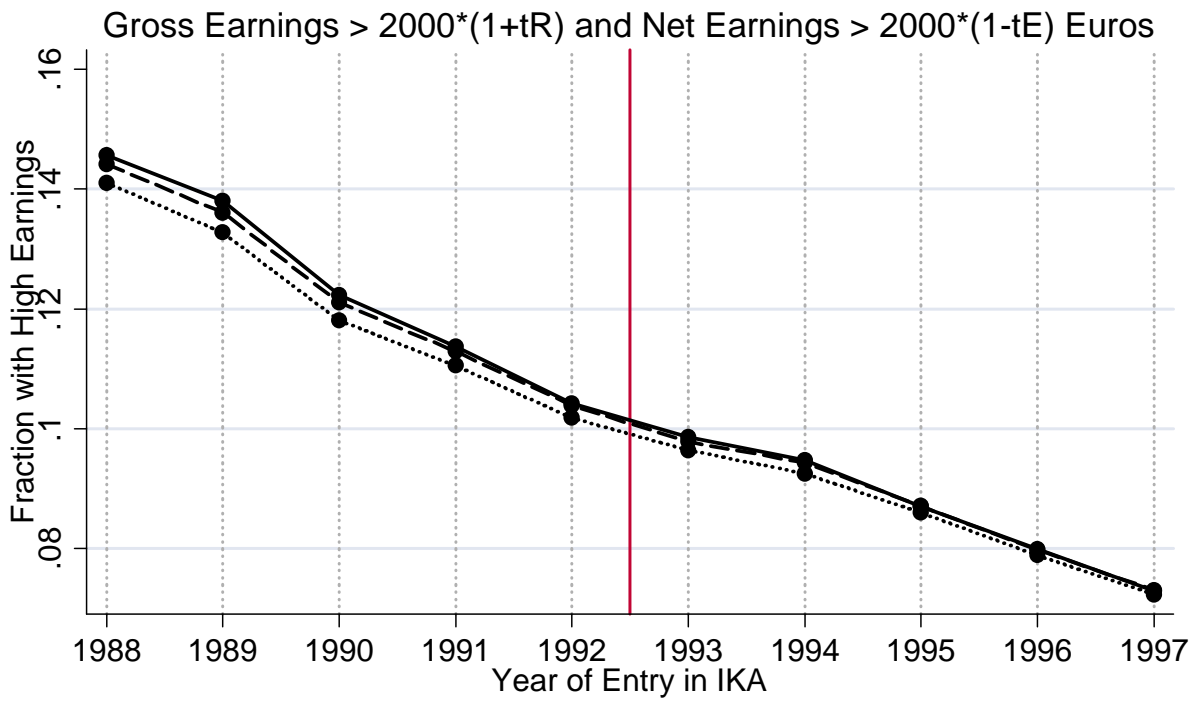

$\longrightarrow$ Gross Earnings - $\rightarrow-$ Posted Earnings

\section{Figure 7: Fraction with Earnings above Threshold}

Panel A displays, by year of entry in IKA, the fraction of workers with monthly gross earnings, posted earnings, and net earnings above $3000 *\left(1+\tau_{\mathrm{R}}\right), 3000$, and $3000 *\left(1-\tau_{\mathrm{E}}\right)$ Euros. The graph shows an upward discontinuity for gross earnings, no discontinuity for posted earnings, and a downward discontinuity for net earnings, at the cut-off date, consistent with results in Figure 6. Panel B offers a placebo test by displaying the fraction of workers with gross earnings, posted earnings, and net earnings above $2000 *\left(1+\tau_{R}\right), 2000$, and $2000 *\left(1-\tau_{E}\right)$ Euros, which are below the old cap and should not be affected by the reform. Both panels combine earnings records for March 2004, March 2005, March 2006, and March 2007 and adjust earnings by $4 \%$ per year so that caps are aligned across years. 


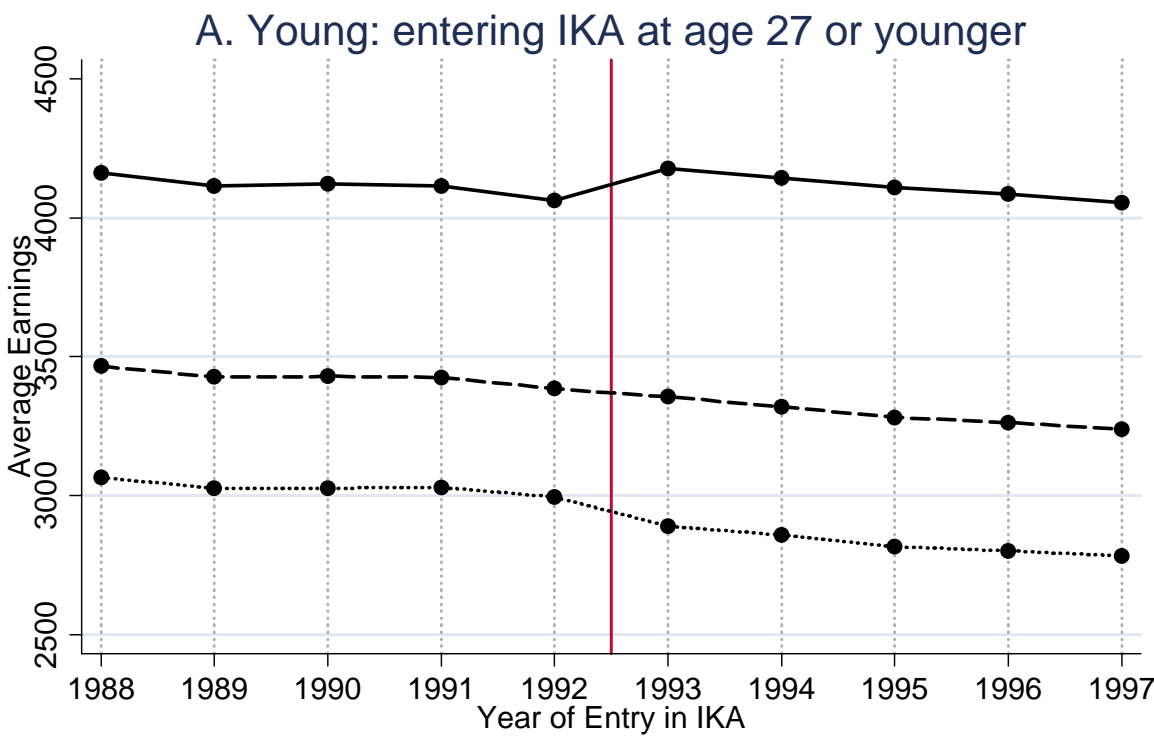

$\longrightarrow$ Gross Earnings $\quad-\bullet-$ Posted Earnings $\cdots \cdots \cdots \cdot \cdots \cdot$ Net Earnings

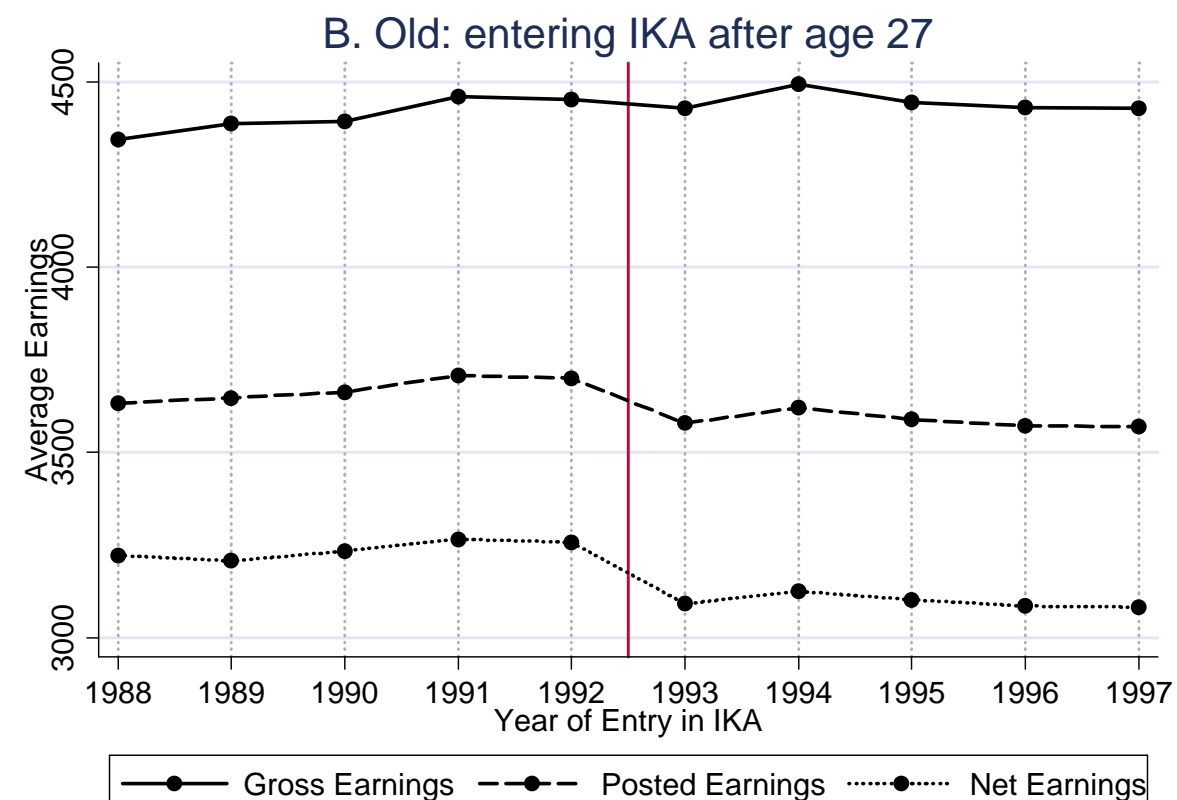

Figure 8: Heterogeneous Effects on Earnings by Age at Entry

Both panels display, by year of entry in IKA, the average monthly gross earnings, posted earnings, and net earnings, capped at the new cap, for all workers above the old cap (as in Figure 5). Both panels combine earnings records for March 2004, March 2005, March 2006, and March 2007. Panel A is for workers aged 27 or less when they entered IKA. Panel B is for workers aged over 27 when they entered IKA. Panel A shows that incidence effects are non standard for young workers (employers compensate workers the extra employer tax burden at the discontinuity and gross earnings jump up) while incidence effects are standard for older workers (employers do not compensate workers for the extra employer tax burden at the discontinuity and gross earnings are flat). Note that $85 \%$ of the sample is young explaining why main results are very close to the results for the young. 

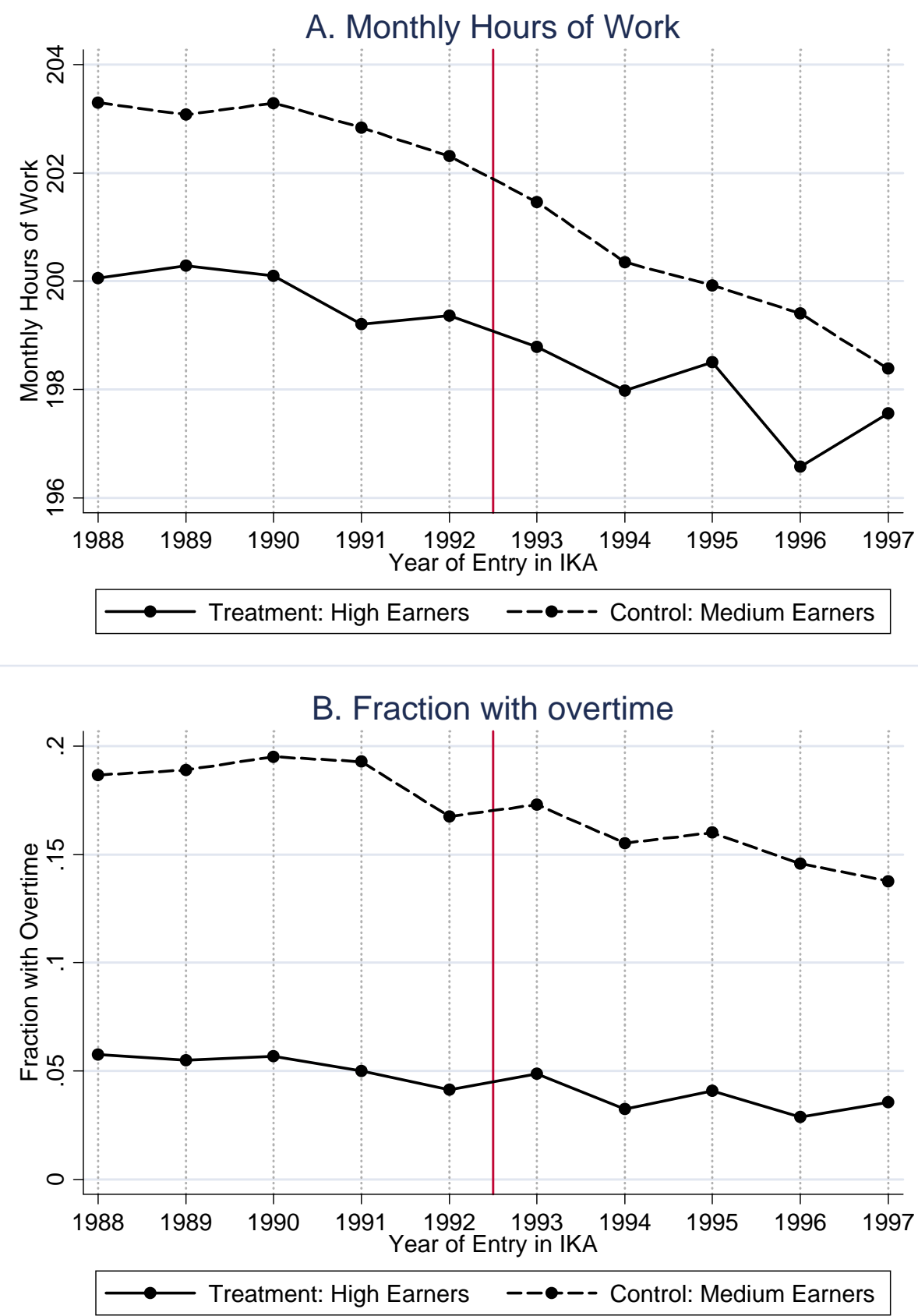

Figure 9. Labor Supply Effects: Monthly Hours of Work and Overtime

Panel A displays, by year of entry in IKA, the average number of monthly hours of work among high earners (defined as those with regular earnings per day of work above 2500/25 Euros, i.e., would reach the old cap by working full month) and among medium earners (defined as those with regular earnings per day of work between 1500/25 and 2000/25 Euros, i.e., would remain below the old cap by working full month). Panel B displays, by year of entry in IKA, the fraction of workers with overtime earnings among the same two groups as in Panel A. The high earner group is affected by the reform while the medium earnings group is not. Earnings records for March 2004, March 2005, March 2006, and March 2007 are combined. In both panels, there is no discontinuity at the cut-off date for the treatment group, suggesting that there is no labor supply response--along the days and overtime margins--to the higher marginal payroll tax rate in the new regime. 

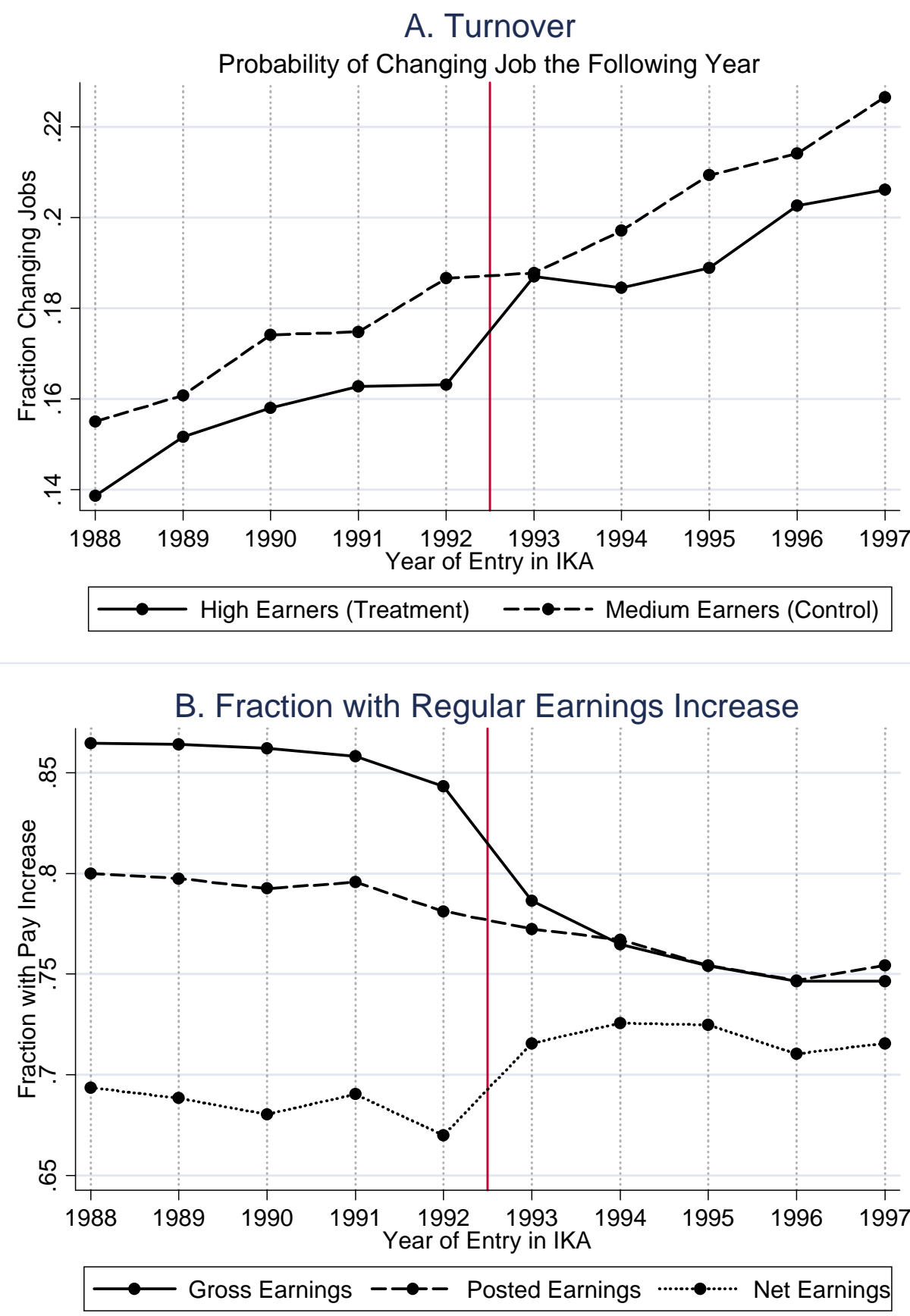

\section{Figure 10: Turnover and Pay Raises}

Panel A displays, by year of entry in IKA, the fraction of workers changing regular jobs from one year to the next among high earners (posted earnings above the old cap and affected by the reform) and medium earners (posted earnings between 1500 Euros and the old cap and not affected by the reform). Panel A suggests that turnover jumps up at the discontinuity for the treatment group. Panel B displays, by year of entry in IKA, the fraction of workers experiencing a nominal regular monthly posted earnings (resp. gross earnings, net earnings) increase the following year for workers with regular earnings above the old cap in base year. Panel B displays a discontinuity for gross earnings and net earnings but not posted earnings, suggesting that pay increase decisions are based on earnings. Earnings records for March 2004, March 2005, and March 2006 are combined. 


\title{
A. Contribution Rates (most common case):
}

\author{
Employer tax rate $\tau_{R}$ Employee tax rate $\tau_{E} \quad \tau=\left(\tau_{R}+\tau_{E}\right) /\left(1+\tau_{R}\right)$
}

Retirement benefits

$16.33 \% \quad 9.67 \%$

Sickness benefits $\quad 5.10 \% \quad 2.55 \%$

Unemployment benefits $\quad 5.53 \% \quad 2.43 \%$

Other benefits $\quad 1.10 \% \quad 1.35 \%$

$\begin{array}{lll}\text { Total } & 28.06 \% & 16.00 \%\end{array}$

$34.41 \%$

\section{B. Monthly Earning Cap for Contributions (2007):}

\section{Old regime}

(individuals with covered earnings before 1/1/1993)

$€ 2,315.00$

New Regime

(individuals with no covered earnings before 1/1/1993)

Panel A displays contribution rates for employees covered by IKA in the most common case (coverage code 101). IKA contributions are assessed as a percentage of monthly earnings and shared between employees and employers. Those contributions fund retirement benefits, sickness benefits, unemployment benefits, and various other benefits. Contributions vary by coverage code corresponding to the occupation/sector of the employee. For example, contribution rates are higher in hazardous occupations. IKA covers a total of 2 million employees (45\% of all active workers in Greece).

Panel B displays the earnings caps for IKA contributions. The cap applies on monthly earnings. The cap for employer contributions is based on the sum of monthly earnings paid to a given employee (including bonuses, overtime, etc.). The cap for employee contributions is based on the sum of monthly earnings from all covered jobs for the given employee (employees with multiple jobs who reach the cap and have overpaid contributions receive a refund from the government). The cap is 2,315 Euros for old regime workers. Old regime workers are workers with positive covered earnings before $1 / 1 / 1993$. The cap is 2.28 times higher at 5279.57 Euro for new regime workers. New regime workers are workers with no covered earnings before $1 / 1 / 1993$. The caps have increased annually by $4 \%$ from 2004 to 2007 . Under the old regime, the cap is prorated on the number of days worked. It is not pro-rated in the case of new regime workers. 
Table 2. Summary Statistics (March 2007)

\begin{tabular}{|c|c|c|c|c|}
\hline & $\begin{array}{c}\begin{array}{c}1988-1992 \\
\text { entrants, } \\
\text { any earnings }\end{array} \\
(1)\end{array}$ & $\begin{array}{c}\begin{array}{c}1993-1997 \\
\text { entrants, } \\
\text { any earnings }\end{array} \\
(2) \\
\end{array}$ & $\begin{array}{c}\begin{array}{c}1988-1992 \\
\text { entrants, } \\
\text { Earnings }>2315 \\
\text { Euros }\end{array} \\
(3) \\
\end{array}$ & $\begin{array}{c}\begin{array}{c}1993-1997 \\
\text { entrants, } \\
\text { Earnings }>2315 \\
\text { Euros }\end{array} \\
(4) \\
\end{array}$ \\
\hline Percent New Regime & $\begin{array}{r}0.2 \% \\
{[4.1 \%]}\end{array}$ & $\begin{array}{r}95.3 \% \\
{[21.1 \%]}\end{array}$ & $\begin{array}{r}0.1 \% \\
{[3.8 \%]}\end{array}$ & $\begin{array}{r}90.5 \% \\
{[29.3 \%]}\end{array}$ \\
\hline Percent Above Old Cap (2315 Euros) & $\begin{array}{r}10.4 \% \\
{[30.5 \%]}\end{array}$ & $\begin{array}{r}7.4 \% \\
{[26.1 \%]}\end{array}$ & $\begin{array}{r}100.0 \% \\
{[0 \%]}\end{array}$ & $\begin{array}{r}100.0 \% \\
{[0 \%]}\end{array}$ \\
\hline Percent Above New Cap (5280 Euros) & $\begin{array}{r}1.5 \% \\
{[12.1 \%]}\end{array}$ & $\begin{array}{r}0.9 \% \\
{[9.5 \%]}\end{array}$ & $\begin{array}{r}14.4 \% \\
{[35.1 \%]}\end{array}$ & $\begin{array}{r}12.5 \% \\
{[33.0 \%]}\end{array}$ \\
\hline Average Monthly Earnings & $\begin{array}{r}€ 1,427 \\
{[2021]}\end{array}$ & $\begin{array}{r}€ 1,262 \\
{[1731]}\end{array}$ & $\begin{array}{r}€ 4,185 \\
{[5396]}\end{array}$ & $\begin{array}{r}€ 3,991 \\
{[5508]}\end{array}$ \\
\hline Average Monthly Regular Earnings & $\begin{array}{r}€ 1,233 \\
{[933]}\end{array}$ & $\begin{array}{r}€ 1,095 \\
{[689]}\end{array}$ & $\begin{array}{r}€ 2,879 \\
{[1929]}\end{array}$ & $\begin{array}{r}€ 2,575 \\
{[1394]}\end{array}$ \\
\hline Percent with Overtime & $\begin{array}{r}11.3 \% \\
{[31.6 \%]}\end{array}$ & $\begin{array}{r}10.5 \% \\
{[30.7 \%]}\end{array}$ & $\begin{array}{r}19.2 \% \\
{[39.4 \%]}\end{array}$ & $\begin{array}{r}16.7 \% \\
{[37.3 \%]}\end{array}$ \\
\hline Percent with Bonuses & $\begin{array}{r}9.4 \% \\
{[29.1 \%]}\end{array}$ & $\begin{array}{r}9.3 \% \\
{[29.1 \%]}\end{array}$ & $\begin{array}{r}36.9 \% \\
{[48.2 \%]}\end{array}$ & $\begin{array}{r}44.8 \% \\
{[49.7 \%]}\end{array}$ \\
\hline Percent Male & $\begin{array}{r}54.2 \% \\
{[49.8 \%]}\end{array}$ & $\begin{array}{r}49.2 \% \\
{[50.0 \%]}\end{array}$ & $\begin{array}{r}68.6 \% \\
{[46.4 \%]}\end{array}$ & $\begin{array}{r}61.6 \% \\
{[48.6 \%]}\end{array}$ \\
\hline Average Age & $\begin{array}{l}39.1 \\
{[5.6]}\end{array}$ & $\begin{array}{l}34.9 \\
{[5.9}\end{array}$ & $\begin{array}{l}40.0 \\
{[4.7]}\end{array}$ & $\begin{array}{l}36.2 \\
{[4.9]}\end{array}$ \\
\hline Number of jobs & $\begin{array}{r}1.036 \\
{[0.217]}\end{array}$ & $\begin{array}{r}1.048 \\
{[0.254]}\end{array}$ & $\begin{array}{r}1.043 \\
{[0.237]}\end{array}$ & $\begin{array}{r}1.056 \\
{[0.274]}\end{array}$ \\
\hline Number of workers in firm & $\begin{array}{r}743 \\
{[1878]}\end{array}$ & $\begin{array}{r}794 \\
{[2035]}\end{array}$ & $\begin{array}{r}1655 \\
{[2491]}\end{array}$ & $\begin{array}{r}1744 \\
{[2575]}\end{array}$ \\
\hline $\begin{array}{l}\text { Percent changed jobs from March '06 } \\
\text { to March '07 } \\
\text { Marginal Tax Rates (MTR) }\end{array}$ & $\begin{array}{r}22.0 \% \\
{[41.4 \%]}\end{array}$ & $\begin{array}{r}25.8 \% \\
{[43.7 \%]}\end{array}$ & $\begin{array}{r}12.1 \% \\
{[32.6 \%]}\end{array}$ & $\begin{array}{r}14.3 \% \\
{[35.0 \%]}\end{array}$ \\
\hline Average employer MTR $\tau_{R}$ & $\begin{array}{l}24.7 \% \\
{[9.0 \%]}\end{array}$ & $\begin{array}{l}26.7 \% \\
{[5.0 \%]}\end{array}$ & $\begin{array}{r}0.6 \% \\
{[4.1 \%]}\end{array}$ & $\begin{array}{r}20.4 \% \\
{[11.0 \%]}\end{array}$ \\
\hline Average employee MTR $\tau_{E}$ & $\begin{array}{l}14.3 \% \\
{[5.5 \%]}\end{array}$ & $\begin{array}{l}15.3 \% \\
{[3.4 \%]}\end{array}$ & $\begin{array}{r}0.1 \% \\
{[1.2 \%]}\end{array}$ & $\begin{array}{l}11.5 \% \\
{[6.4 \%]}\end{array}$ \\
\hline Average total MTR $\tau=\left(\tau_{R}+\tau_{E}\right) /\left(1+\tau_{R}\right)$ & $\begin{array}{r}30.5 \% \\
{[11.0 \%]}\end{array}$ & $\begin{array}{l}32.9 \% \\
{[6.0 \%]}\end{array}$ & $\begin{array}{r}0.6 \% \\
{[3.8 \%]}\end{array}$ & $\begin{array}{r}25.3 \% \\
{[13.5 \%]}\end{array}$ \\
\hline Number of Observations: & 208,374 & 225,758 & 21,648 & 16,624 \\
\hline
\end{tabular}

The table displays summary statistics for 4 groups of individuals with Greek citizenship with positive IKA covered earnings as of March 2007. Column (1) is the set of individuals who entered IKA (i.e., started having covered IKA earnings) from 1988 to 1992 (old regime). Column (2) is the set of individuals who entered IKA (i.e., started having covered IKA earnings) from 1993 to 1997 (new regime). Column (3) includes 1988-1992 entrants with total monthly earnings above 2315 Euros in March 2007 (old regime cap). Column (4) includes 1993-1997 entrants with total monthly earnings above 2315 Euros in March 2007 (old regime cap).

The Table reports means and standard deviations in brackets. The percent new regime is not $100 \%$ for $1993-1997$ entrants because individuals who can prove they had covered earnings in another insurance scheme before 1/1/1993 qualify for the old regime under IKA rules. Number of workers in firm is the average number of employees in the firm the individual has his main job (defined as highest regular earnings). A change of job from March '06 to March '07 is defined as a change in the employer for the main job (where regular earnings are highest). Earnings are defined as earnings upon which payroll taxes are computed (posted earnings). Regular earnings include only base pay and exclude bonuses, overtime, and other forms of earnings. The Marginal Tax Rates (MTR) are set equal to zero when the individual reaches the earnings cap corresponding to his/her regime. 
Table 3. First Stage Results and Identification Checks

\begin{tabular}{|c|c|c|c|c|c|}
\hline SAMPLE: & $\begin{array}{c}\begin{array}{c}1988-1997 \\
\text { entrants }\end{array} \\
(1) \\
\end{array}$ & $\begin{array}{c}\begin{array}{c}1991-1994 \\
\text { entrants only }\end{array} \\
(2) \\
\end{array}$ & $\begin{array}{c}\begin{array}{c}1988-1997 \\
\text { entrants }\end{array} \\
(3) \\
\end{array}$ & $\begin{array}{c}\begin{array}{c}1988-1997 \\
\text { entrants }\end{array} \\
(4) \\
\end{array}$ & $\begin{array}{c}\begin{array}{c}1988-1997 \\
\text { entrants }\end{array} \\
(5) \\
\end{array}$ \\
\hline \multicolumn{6}{|l|}{$\begin{array}{l}\text { OUTCOMES: } \\
\text { A. First Stage }\end{array}$} \\
\hline Percent in new Regime (\%) & $\begin{array}{l}89.25 \\
(0.12)\end{array}$ & $\begin{array}{l}89.39 \\
(0.22)\end{array}$ & $\begin{array}{l}89.12 \\
(0.12)\end{array}$ & $\begin{array}{l}87.38 \\
(0.19)\end{array}$ & $\begin{array}{l}88.96 \\
(0.26)\end{array}$ \\
\hline Percent with earnings above cap (\%) & $\begin{array}{r}-5.87 \\
(0.14)\end{array}$ & $\begin{array}{r}-5.35 \\
(0.22)\end{array}$ & $\begin{array}{l}-5.89 \\
(0.14)\end{array}$ & $\begin{array}{l}-5.37 \\
(0.21)\end{array}$ & $\begin{array}{l}-5.24 \\
(0.29)\end{array}$ \\
\hline Total MTR $\tau=\left(\tau_{R}+\tau_{E}\right) /\left(1+\tau_{R}\right)(\%)$ & $\begin{array}{r}1.74 \\
(0.05)\end{array}$ & $\begin{array}{r}1.63 \\
(0.09)\end{array}$ & $\begin{array}{r}1.74 \\
(0.05)\end{array}$ & $\begin{array}{r}1.59 \\
(0.08)\end{array}$ & $\begin{array}{r}1.61 \\
(0.11)\end{array}$ \\
\hline \multicolumn{6}{|l|}{ B. Identification Checks } \\
\hline Number of monthly entrants & $\begin{array}{r}-690 \\
(347)\end{array}$ & $\begin{array}{r}-536 \\
(531)\end{array}$ & $\begin{array}{r}-529 \\
(291)\end{array}$ & $\begin{array}{r}22 \\
(430)\end{array}$ & $\begin{array}{r}-579 \\
(595)\end{array}$ \\
\hline $\begin{array}{l}\text { Number of monthly entrants } \\
\text { with posted earnings above old cap }\end{array}$ & $\begin{array}{r}-44 \\
(28)\end{array}$ & $\begin{array}{r}-46 \\
(45)\end{array}$ & $\begin{array}{r}-29 \\
(25)\end{array}$ & $\begin{array}{r}10 \\
(37)\end{array}$ & $\begin{array}{r}-51 \\
(50)\end{array}$ \\
\hline Age (in years) & $\begin{array}{r}0.075 \\
(0.037)\end{array}$ & $\begin{array}{r}0.233 \\
(0.061)\end{array}$ & $\begin{array}{r}-0.024 \\
(0.037)\end{array}$ & $\begin{array}{r}-0.022 \\
(0.056)\end{array}$ & $\begin{array}{r}0.080 \\
(0.078)\end{array}$ \\
\hline Gender (\% male) & $\begin{array}{r}-3.14 \\
(0.31)\end{array}$ & $\begin{array}{r}0.09 \\
(0.49)\end{array}$ & $\begin{array}{r}-3.24 \\
(0.31)\end{array}$ & $\begin{array}{r}-0.03 \\
(0.46)\end{array}$ & $\begin{array}{r}0.33 \\
(0.64)\end{array}$ \\
\hline $\begin{array}{l}\text { Average posted earnings } \\
\text { (capped at old cap, in Euros) }\end{array}$ & $\begin{array}{l}7.76 \\
(3.35)\end{array}$ & $\begin{array}{l}9.00 \\
(5.36)\end{array}$ & $\begin{array}{c}7.52 \\
(3.41)\end{array}$ & $\begin{array}{c}8.52 \\
(5.05)\end{array}$ & $\begin{array}{c}3.88 \\
(6.94)\end{array}$ \\
\hline \multicolumn{6}{|l|}{ Included Controls } \\
\hline $\begin{array}{l}\text { Linear entry date trends } \\
\text { Monthly dummies } \\
\text { Quadratic date trends } \\
\text { Cubic entry date trends }\end{array}$ & Yes & Yes & $\begin{array}{l}\text { Yes } \\
\text { Yes }\end{array}$ & $\begin{array}{l}\text { Yes } \\
\text { Yes } \\
\text { Yes }\end{array}$ & $\begin{array}{l}\text { Yes } \\
\text { Yes } \\
\text { Yes } \\
\text { Yes }\end{array}$ \\
\hline Number of Observations: & 434,132 & 166,895 & 434,132 & 434,132 & 434,132 \\
\hline
\end{tabular}

The table displays the coefficients (with standard errors in parentheses) from regressing various outcomes (listed in the lefthand-side column) on a dummy for entering IKA on or after 1/1/1993 (which corresponds to new regime with higher earnings cap). The sample includes all entrants with positive monthly earnings in March 2007 (results are very similar in the other March 2004, March 2005, or March 2006 samples).

Column (1) estimates includes a linear entry date (normalized to 0 at 1/1/1993) and a linear entry date interacted with the dummy for entering IKA after 1/1/1993. Column (2) uses the same controls as column (1) but limits the sample to those entering IKA from 1991 to 1994. Column (3-5) use all 1988-1997 entrants but add successively Monthly dummies (col. 3), quadratic date trends (quadratic term and quadratic term interacted with the dummy for entering IKA after 1/1/1993), cubic date trends (cubic term and cubic term interacted with the dummy for entering IKA after 1/1/1993).

New regime is a dummy for being in the new regime (with the higher cap). Earnings above cap is a dummy for having earnings above the payroll tax earnings cap corresponding to the regime the individual is in. Total MTR is based on combined employee and employer payroll tax rates and set at zero when the individual is above cap. In the case of the "number of entrants" outcome variable, we collapse the data by month of entry and run the regression at the monthly level (120 observations with 1988-1997 entrants, and 48 observations with 1991-1994 entrants). Average earnings (capped at old cap) is equal to min(earnings,2315) where 2315 is the old cap earnings level (average earnings below the cap should not be affected by the regime change). 
Table 4. Effects on Average Earnings above Old Cap

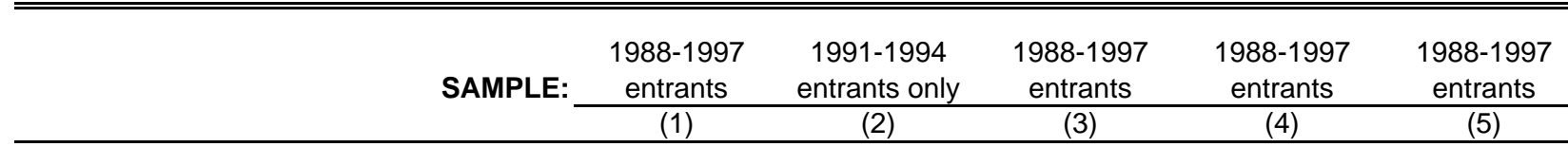

OUTCOMES:

A. Individuals with earnings above old cap and capping earnings at new cap:

$\begin{array}{lrrrrr}\text { Gross Earnings z } & 111 & 144 & 104 & 108 & 139 \\ \text { Posted Earnings w } & (22) & (36) & (23) & (34) & (47) \\ & -29 & 2 & -35 & -25 & (28) \\ \text { Net Earnings c } & (18) & (30) & (18) & -97 & (38) \\ & -99 & -74 & -105 & (24) & (34) \\ \text { Number of Observations: } & (16) & (26) & (16) & 127,396 & 127,396\end{array}$

B. Individuals with regular earnings above old cap and capping earnings at new cap:

$\begin{array}{lrrrrr}\text { Regular Gross Earnings z } & 94 & 137 & 86 & 97 & 129 \\ & (29) & (47) & (29) & (44) & (62) \\ \text { Regular Posted Earnings w } & -40 & 5 & -48 & (25 & (37) \\ & (24) & (39) & -61) & (51) \\ \text { Regular Net Earnings c } & -106 & (35) & (22) & (33) & (45) \\ & (21) & (35) & 74,543 & 74,543\end{array}$

\section{Placebo: Individuals with earnings above 1500 Euros and capping earnings at old cap:}

\begin{tabular}{|c|c|c|c|c|c|}
\hline Gross Earnings z & $\begin{array}{r}1.5 \\
(4.0)\end{array}$ & $\begin{array}{r}-5.2 \\
(6.4)\end{array}$ & $\begin{array}{r}0.8 \\
(4.0)\end{array}$ & $\begin{array}{r}-9.8 \\
(6.0)\end{array}$ & $\begin{array}{r}-4.1 \\
(8.3)\end{array}$ \\
\hline \multirow[t]{2}{*}{ Posted Earnings w } & 2.1 & -6.2 & 1.9 & -8.3 & -6.6 \\
\hline & (3.1) & $(5.0)$ & (3.2) & $(4.8)$ & (6.6) \\
\hline \multirow[t]{2}{*}{ Net Earnings c } & 2.6 & -7.8 & 2.7 & -8.4 & -9.0 \\
\hline & $(2.9)$ & $(4.7)$ & $(2.9)$ & $(4.4)$ & $(6.0)$ \\
\hline Number of Observations: & 357,348 & 136,985 & 357,348 & 357,348 & 357,348 \\
\hline \multicolumn{6}{|l|}{ Included Controls } \\
\hline Linear entry date trends & Yes & Yes & Yes & Yes & Yes \\
\hline Monthly dummies & & & Yes & Yes & Yes \\
\hline Quadratic date trends & & & & Yes & Yes \\
\hline Cubic entry date trends & & & & & Yes \\
\hline
\end{tabular}

The table displays the coefficients (with standard errors in parentheses) from regressing various earnings outcomes (listed in the lefthand-side column) on a dummy for entering IKA on or after 1/1/1993 (which corresponds to new regime with higher earnings cap). The sample combines the 4 waves March 2004, March 2005, March 2006, March 2007. Standard errors are clustered by individual. Earnings before 2007 are inflated by $4 \%$ per year so that caps coincide exactly across the 4 waves.

Column (1) estimates includes a linear entry date (normalized to 0 at 1/1/1993) and a linear entry date interacted with the dummy for entering IKA after 1/1/1993. Column (2) uses the same controls as column (1) but limits the sample to those entering IKA from 1991 to 1994. Column (3-5) use all 1988-1997 entrants but add successively Monthly dummies (col. 3), quadratic date trends (quadratic term and quadratic term interacted with the dummy for entering IKA after 1/1/1993), cubic date trends (cubic term and cubic term interacted with the dummy for entering IKA after 1/1/1993).

In panel $A$, the sample includes all entrants with monthly posted earnings above 2315 Euros (old cap). Posted earnings are capped at the new cap (5280 Euros) (i.e., earnings above 5280 Euros are replaced by 5280$)$. Gross earnings are capped at $5280^{*}\left(1+\tau_{R}\right)($ gross earnings new cap) and net earnings are capped at $5280^{\star}\left(1-\tau_{E}\right)$ (net earnings new cap). In panel $B$, the sample includes all entrants with regular monthly earnings above 2315 Euros (old cap). Regular earnings (gross, posted, and net) are also capped at the new caps $\left(5280 *\left(1+\tau_{R}\right), 5280\right.$, and $5280 *\left(1-\tau_{E}\right)$ Euros). In panel C, the sample includes all entrants with monthly posted earnings above 1500 Euros. Posted earnings are capped at the old cap (2315 Euros). Gross earnings are capped at $2315^{\star}\left(1+\tau_{R}\right)$ and net earnings are capped at $2315^{\star}\left(1-\tau_{E}\right)$. 
Table 5. Effects on Probability of High Earnings

\begin{tabular}{|c|c|c|c|c|c|c|}
\hline & \multicolumn{3}{|c|}{ 1988-1997 entrants } & \multicolumn{3}{|c|}{ 1991-1994 entrants only } \\
\hline & $\begin{array}{c}\begin{array}{c}\text { Gross } \\
\text { Earnings }\end{array} \\
(1)\end{array}$ & $\begin{array}{c}\text { Posted } \\
\text { Earnings } \\
(2)\end{array}$ & $\begin{array}{c}\begin{array}{c}\text { Net } \\
\text { Earnings }\end{array} \\
(3)\end{array}$ & $\begin{array}{c}\begin{array}{c}\text { Gross } \\
\text { Earnings }\end{array} \\
(4)\end{array}$ & $\begin{array}{l}\text { Posted } \\
\text { Earnings } \\
(5)\end{array}$ & $\begin{array}{c}\begin{array}{c}\text { Net } \\
\text { Earnings }\end{array} \\
(6)\end{array}$ \\
\hline \multicolumn{7}{|l|}{ OUTCOMES: } \\
\hline \multicolumn{7}{|l|}{ A. Total Earnings: } \\
\hline Percent with Earnings above 3000 Euros: & $\begin{array}{r}0.494 \\
(0.094)\end{array}$ & $\begin{array}{r}0.135 \\
(0.097)\end{array}$ & $\begin{array}{r}-0.134 \\
(0.099)\end{array}$ & $\begin{array}{r}0.301 \\
(0.147)\end{array}$ & $\begin{array}{r}-0.079 \\
(0.153)\end{array}$ & $\begin{array}{r}-0.353 \\
(0.156)\end{array}$ \\
\hline Percent with Earnings above 5000 Euros: & $\begin{array}{r}0.148 \\
(0.047)\end{array}$ & $\begin{array}{r}-0.043 \\
(0.052)\end{array}$ & $\begin{array}{r}-0.208 \\
(0.055)\end{array}$ & $\begin{array}{r}0.178 \\
(0.075)\end{array}$ & $\begin{array}{r}0.019 \\
(0.082)\end{array}$ & $\begin{array}{r}-0.139 \\
(0.087)\end{array}$ \\
\hline $\begin{array}{l}\text { Percent with Earnings above } 2000 \text { Euros: } \\
\text { (Placebo) }\end{array}$ & $\begin{array}{r}0.546 \\
(0.158)\end{array}$ & $\begin{array}{r}0.482 \\
(0.157)\end{array}$ & $\begin{array}{r}0.500 \\
(0.154)\end{array}$ & $\begin{array}{r}0.175 \\
(0.250)\end{array}$ & $\begin{array}{r}0.031 \\
(0.248)\end{array}$ & $\begin{array}{r}0.068 \\
(0.244)\end{array}$ \\
\hline Number of Observations: & $1,781,559$ & $1,781,559$ & $1,781,559$ & 685,415 & 685,415 & 685,415 \\
\hline \multicolumn{7}{|l|}{ B. Regular Earnings: } \\
\hline Percent with Earnings above 3000 Euros: & $\begin{array}{r}0.220 \\
(0.071)\end{array}$ & $\begin{array}{r}-0.004 \\
(0.074)\end{array}$ & $\begin{array}{r}-0.173 \\
(0.076)\end{array}$ & $\begin{array}{r}0.186 \\
(0.112)\end{array}$ & $\begin{array}{r}0.002 \\
(0.118)\end{array}$ & $\begin{array}{r}-0.153 \\
(0.120)\end{array}$ \\
\hline Percent with Earnings above 5000 Euros: & $\begin{array}{r}0.035 \\
(0.032)\end{array}$ & $\begin{array}{r}-0.081 \\
(0.036)\end{array}$ & $\begin{array}{r}-0.173 \\
(0.039)\end{array}$ & $\begin{array}{r}0.079 \\
(0.052)\end{array}$ & $\begin{array}{r}-0.031 \\
(0.058)\end{array}$ & $\begin{array}{r}-0.111 \\
(0.061)\end{array}$ \\
\hline $\begin{array}{l}\text { Percent with Earnings above } 2000 \text { Euros: } \\
\text { (Placebo) }\end{array}$ & $\begin{array}{r}0.167 \\
(0.132)\end{array}$ & $\begin{array}{r}0.148 \\
(0.131)\end{array}$ & $\begin{array}{r}0.141 \\
(0.128)\end{array}$ & $\begin{array}{r}0.072 \\
(0.208)\end{array}$ & $\begin{array}{r}-0.009 \\
(0.206)\end{array}$ & $\begin{array}{r}0.006 \\
(0.202)\end{array}$ \\
\hline Number of Observations: & $1,781,624$ & $1,781,624$ & $1,781,624$ & 685,439 & 685,439 & 685,439 \\
\hline
\end{tabular}

The table displays the coefficients (with standard errors in parentheses) from regressing various outcomes (listed in the left-hand-side column) on a dummy for entering IKA on or after 1/1/1993 (which corresponds to new regime with higher earnings cap), and linear controls in date of entry and date of entry interacted with post 1/1/1993 dummy as in colmuns (1) and (2) of Table 4 . The sample combines the 4 waves March 2004, March 2005, March 2006, March 2007. Standard errors are clustered by individual. Earnings before 2007 are inflated by $4 \%$ per year so that caps coincide exactly across the 4 waves. Columns (1) to (3) are based on all 1988-1997 entrants while columns (4) to (6) restrict the sample to 1991-1994 entrants. Outcomes are based on gross earnings in columns (1) and (4), on earnings in columns (2) and (5), and on net earnings in columns (3) and (6).

In panel $A$, the sample includes all individuals with positive earnings. In panel $B$, the sample includes all individual with positive regular earnings. All estimates are expressed in percent (i.e., each left-hand-side variable dummy is set equal to 0 or 100). 
Table 6. Effects on Earnings: Heterogeneity across Groups

\begin{tabular}{|c|c|c|c|c|c|c|}
\hline & \multicolumn{3}{|c|}{ 1988-1997 entrants } & \multicolumn{3}{|c|}{ 1991-1994 entrants only } \\
\hline & $\begin{array}{c}\begin{array}{c}\text { Gross } \\
\text { Earnings }\end{array} \\
(1)\end{array}$ & $\begin{array}{l}\begin{array}{c}\text { Posted } \\
\text { Earnings }\end{array} \\
(2)\end{array}$ & $\begin{array}{c}\begin{array}{c}\text { Net } \\
\text { Earnings }\end{array} \\
(3)\end{array}$ & $\begin{array}{c}\begin{array}{c}\text { Gross } \\
\text { Earnings }\end{array} \\
(4)\end{array}$ & $\begin{array}{c}\begin{array}{c}\text { Posted } \\
\text { Earnings }\end{array} \\
(5)\end{array}$ & $\begin{array}{c}\begin{array}{c}\text { Net } \\
\text { Earnings }\end{array} \\
(6)\end{array}$ \\
\hline \multicolumn{7}{|c|}{ OUTCOMES: Average Earnings (capped at new cap) for individuals with earnings above old cap } \\
\hline \multicolumn{7}{|l|}{ A. Age Effects: } \\
\hline $\begin{array}{l}\text { Young workers } \\
\text { (aged } 27 \text { or less when entering IKA) }\end{array}$ & $\begin{array}{l}127 \\
(23)\end{array}$ & $\begin{array}{r}-19 \\
(19)\end{array}$ & $\begin{array}{r}-94 \\
(17)\end{array}$ & $\begin{array}{r}158 \\
(38)\end{array}$ & $\begin{array}{r}11 \\
(31)\end{array}$ & $\begin{array}{r}-69 \\
(28)\end{array}$ \\
\hline Number of Observations: & 107,082 & 107,082 & 107,082 & 40,299 & 40,299 & 40,299 \\
\hline $\begin{array}{l}\text { Older workers } \\
\text { (aged over } 27 \text { when entering IKA) }\end{array}$ & $\begin{array}{r}-19 \\
(62)\end{array}$ & $\begin{array}{r}-117 \\
(50)\end{array}$ & $\begin{array}{r}-160 \\
(44)\end{array}$ & $\begin{array}{r}-1 \\
(100)\end{array}$ & $\begin{array}{r}-107 \\
(81)\end{array}$ & $\begin{array}{r}-155 \\
(71)\end{array}$ \\
\hline Number of Observations: & 20,314 & 20,314 & 20,314 & 8,030 & 8,030 & 8,030 \\
\hline \multicolumn{7}{|l|}{ B. Gender Effects: } \\
\hline Male Workers & $\begin{array}{l}131 \\
(28)\end{array}$ & $\begin{array}{r}-13 \\
(23)\end{array}$ & $\begin{array}{r}-86 \\
(20)\end{array}$ & $\begin{array}{l}147 \\
(46)\end{array}$ & $\begin{array}{r}3 \\
(37)\end{array}$ & $\begin{array}{r}-72 \\
(33)\end{array}$ \\
\hline Number of Observations: & 83,846 & 83,846 & 83,846 & 32,001 & 32,001 & 32,001 \\
\hline Female Workers & $\begin{array}{l}100 \\
(35)\end{array}$ & $\begin{array}{r}-43 \\
(29)\end{array}$ & $\begin{array}{r}-115 \\
(26)\end{array}$ & $\begin{array}{l}151 \\
(57)\end{array}$ & $\begin{array}{r}7 \\
(47)\end{array}$ & $\begin{array}{r}-72 \\
(42)\end{array}$ \\
\hline Number of Observations: & 43,550 & 43,550 & 43,550 & 16,328 & 16,328 & 16,328 \\
\hline \multicolumn{7}{|l|}{ C. Firm's size: } \\
\hline Small firms (<400 workers) & $\begin{array}{l}117 \\
(31)\end{array}$ & $\begin{array}{r}-20 \\
(25)\end{array}$ & $\begin{array}{r}-90 \\
(22)\end{array}$ & $\begin{array}{l}122 \\
(51)\end{array}$ & $\begin{array}{r}-2 \\
(42)\end{array}$ & $\begin{array}{r}-66 \\
(36)\end{array}$ \\
\hline Number of Observations: & 65,531 & 65,531 & 65,531 & 24,944 & 24,944 & 24,944 \\
\hline Large firms (>400 workers) & $\begin{array}{r}114 \\
(30)\end{array}$ & $\begin{array}{r}-34 \\
(25)\end{array}$ & $\begin{array}{r}-108 \\
(22)\end{array}$ & $\begin{array}{r}169 \\
(49)\end{array}$ & $\begin{array}{r}6 \\
(41)\end{array}$ & $\begin{array}{r}-83 \\
(36)\end{array}$ \\
\hline Number of Observations: & 61,865 & 61,865 & 61,865 & 23,385 & 23,385 & 23,385 \\
\hline
\end{tabular}

The table displays the coefficients (with standard errors in parentheses) from regressing earnings outcomes on a dummy for entering IKA on or after 1/1/1993 (which corresponds to new regime with higher earnings cap), and linear controls in date of entry and date of entry interacted with post 1/1/1993 dummy as in colmuns (1) and (2) of Table 4. The sample combines the 4 waves March 2004, March 2005, March 2006, March 2007. Standard errors are clustered by individual. Earnings before 2007 are inflated by $4 \%$ per year so that caps coincide exactly across the 4 waves. Columns (1) to (3) are based on all 1988-1997 entrants while columns (4) to (6) restrict the sample to 1991-1994 entrants. Outcomes are based on gross earnings in columns (1) and (4), on posted earnings in columns (2) and (5), and on net earnings in columns (3) and (6). In all cases, the left-hand-side variable is earnings capped at the new cap, and the sample is always limited to workers with earnings above the old cap.

Panel A focuses on age effects and uses total earnings. In the first row of estimates, the sample is limited to workers entering IKA at age 27 or younger. In the second row, the sample is limited to older workers entering IKA after age 27. Panel B focuses on gender effects and uses total earnings. In the first row of estimates, the sample is limited to male workers. In the second row, the sample is limited to female workers. Panel $\mathrm{C}$ focuses on firm's size effects and uses total earnings. In the first row of estimates, the sample is limited to workers in small firms (defined as firms with less than 400 workers). In the second row, the sample is limited to workers in large firms (>400 workers). 
Table 7. Labor Supply, Turnover, and Pay Raises Effects

\begin{tabular}{|c|c|c|c|c|c|}
\hline SAMPLE: & $\begin{array}{c}\begin{array}{c}1988-1997 \\
\text { entrants }\end{array} \\
(1)\end{array}$ & $\begin{array}{c}\begin{array}{c}1991-1994 \\
\text { entrants only }\end{array} \\
(2)\end{array}$ & $\begin{array}{c}\begin{array}{c}1988-1997 \\
\text { entrants }\end{array} \\
(3)\end{array}$ & $\begin{array}{c}\begin{array}{c}1988-1997 \\
\text { entrants }\end{array} \\
(4)\end{array}$ & $\begin{array}{c}\begin{array}{c}1988-1997 \\
\text { entrants }\end{array} \\
(5)\end{array}$ \\
\hline \multicolumn{6}{|l|}{ OUTCOMES: } \\
\hline \multicolumn{6}{|c|}{ A. Labor Supply (workers with daily regular earnings above old cap) } \\
\hline Number of Days in Regular Job & $\begin{array}{r}0.006 \\
(0.035)\end{array}$ & $\begin{array}{r}-0.052 \\
(0.055)\end{array}$ & $\begin{array}{r}-0.002 \\
(0.036)\end{array}$ & $\begin{array}{r}-0.070 \\
(0.053)\end{array}$ & $\begin{array}{r}-0.077 \\
(0.070)\end{array}$ \\
\hline Percent with Overtime & $\begin{array}{r}0.36 \\
(0.53)\end{array}$ & $\begin{array}{r}2.20 \\
(0.85)\end{array}$ & $\begin{array}{r}0.17 \\
(0.54)\end{array}$ & $\begin{array}{r}1.73 \\
(0.80)\end{array}$ & $\begin{array}{r}1.91 \\
(1.08)\end{array}$ \\
\hline Percent with Bonus & $\begin{array}{r}1.80 \\
(1.08)\end{array}$ & $\begin{array}{r}2.09 \\
(1.75)\end{array}$ & $\begin{array}{r}1.94 \\
(1.10)\end{array}$ & $\begin{array}{r}1.30 \\
(1.64)\end{array}$ & $\begin{array}{r}3.53 \\
(2.27)\end{array}$ \\
\hline Percent with Multiple Jobs & $\begin{array}{r}0.24 \\
(0.44)\end{array}$ & $\begin{array}{r}0.61 \\
(0.69)\end{array}$ & $\begin{array}{r}0.09 \\
(0.46)\end{array}$ & $\begin{array}{r}-0.15 \\
(0.65)\end{array}$ & $\begin{array}{r}0.94 \\
(0.86)\end{array}$ \\
\hline Hours of work & $\begin{array}{r}-0.161 \\
(0.495)\end{array}$ & $\begin{array}{r}0.241 \\
(0.781)\end{array}$ & $\begin{array}{l}-0.355 \\
(0.507)\end{array}$ & $\begin{array}{r}0.258 \\
(0.739)\end{array}$ & $\begin{array}{r}-0.916 \\
(1.006)\end{array}$ \\
\hline $\begin{array}{l}\text { Elasticity of hours of work with respect to } \\
\text { the net of employee payroll tax rate }\end{array}$ & $\begin{array}{r}0.019 \\
(0.035)\end{array}$ & $\begin{array}{r}0.007 \\
(0.065)\end{array}$ & $\begin{array}{r}0.032 \\
(0.035)\end{array}$ & $\begin{array}{r}0.001 \\
(0.061)\end{array}$ & $\begin{array}{r}0.134 \\
(0.097)\end{array}$ \\
\hline Number of Observations: & 57,675 & 21,593 & 57,675 & 57,675 & 57,675 \\
\hline \multicolumn{6}{|c|}{ B. Turnover (Workers with total earnings above old cap) } \\
\hline Percent Changing Jobs Next Year & $\begin{array}{r}0.77 \\
(0.56)\end{array}$ & $\begin{array}{r}1.97 \\
(0.90)\end{array}$ & $\begin{array}{r}0.90 \\
(0.57)\end{array}$ & $\begin{array}{r}2.57 \\
(0.85)\end{array}$ & $\begin{array}{r}2.26 \\
(1.17)\end{array}$ \\
\hline Number of Observations: & 89,124 & 33,781 & 89,124 & 89,124 & 89,124 \\
\hline \multicolumn{6}{|c|}{ C. Nominal Regular Earnings Raise (Workers with regular earnings above old cap) } \\
\hline Percent with nominal gross reg. earnings raise & $\begin{array}{r}-6.13 \\
(0.78)\end{array}$ & $\begin{array}{r}-3.87 \\
(1.25)\end{array}$ & $\begin{array}{l}-6.16 \\
(0.79)\end{array}$ & $\begin{array}{r}-4.36 \\
(1.18)\end{array}$ & $\begin{array}{r}-3.78 \\
(1.61)\end{array}$ \\
\hline Percent with nominal reg. posted earnings raise & $\begin{array}{r}-1.00 \\
(0.82)\end{array}$ & $\begin{array}{r}0.10 \\
(1.32)\end{array}$ & $\begin{array}{l}-0.98 \\
(0.83)\end{array}$ & $\begin{array}{r}0.00 \\
(1.25)\end{array}$ & $\begin{array}{r}-0.43 \\
(1.71)\end{array}$ \\
\hline Percent with nominal net reg. earnings raise & $\begin{array}{r}4.82 \\
(0.96)\end{array}$ & $\begin{array}{r}5.00 \\
(1.56)\end{array}$ & $\begin{array}{r}4.91 \\
(0.97)\end{array}$ & $\begin{array}{r}4.29 \\
(1.46)\end{array}$ & $\begin{array}{r}3.41 \\
(2.03)\end{array}$ \\
\hline Number of Observations: & 48,962 & 18,422 & 48,962 & 48,962 & 48,962 \\
\hline \multicolumn{6}{|l|}{ Included Controls } \\
\hline $\begin{array}{l}\text { Linear entry date trends } \\
\text { Monthly dummies } \\
\text { Quadratic date trends } \\
\text { Cubic entry date trends }\end{array}$ & Yes & Yes & $\begin{array}{l}\text { Yes } \\
\text { Yes }\end{array}$ & $\begin{array}{l}\text { Yes } \\
\text { Yes } \\
\text { Yes }\end{array}$ & $\begin{array}{l}\text { Yes } \\
\text { Yes } \\
\text { Yes } \\
\text { Yes }\end{array}$ \\
\hline
\end{tabular}

The table displays the coefficients (with standard errors in parentheses) from regressing various outcomes (listed in the left-hand-side column) on a dummy for entering IKA on or after 1/1/1993 (which corresponds to new regime with higher earnings cap). The sample combines the 4 waves March 2004, March 2005, March 2006, March 2007. Standard errors are clustered by individual. Earnings before 2007 are inflated by $4 \%$ per year so that caps coincide exactly across the 4 waves. For all dummy outcomes, estimates are expressed in percent (i.e., the dummy is set equal to 0 or 100 in the regression).

Column (1) estimates includes a linear entry date (normalized to 0 at 1/1/1993) and a linear entry date interacted with the dummy for entering IKA after 1/1/1993. Column (2) uses the same controls as column (1) but limits the sample to those entering IKA from 1991 to 1994. Column (35) use all 1988-1997 entrants but add successively Monthly dummies (col. 3), quadratic date trends (quadratic term and quadratic term interacted with the dummy for entering IKA after 1/1/1993), cubic date trends (cubic term and cubic term interacted with the dummy for entering IKA after 1/1/1993).

In panel A, the sample is limited to workers with regular earnings per day of work above 2500/25 Euros, i.e., would reach the old cap by working full month. Number of days is the recorded number of days worked during the month. Percent with Overtime is a dummy for having positive overtime earnings. Percent bonus is a dummy for having positive bonus earnings. Percent with Multiple jobs is a dummy for having positive earnings from more than one employer. Monthly hours of work are estimated as number of days in the regular job times 8 (or 4 if part-day) times (1+overtime earnings/regular earnings). Monthly hours are capped at 300. The elasticity of hours of work is obtained from a 2SLS regression of $\log$ (hours) on $\log (1$-tE) where tE is employee marginal payroll tax rate instrumented with a dummy for entering IKA after 1/1/1993 (and adding controls as in the other OLS regressions in the table).

In Panel B, the sample is limited to workers with earnings in base year above the old cap. Percent changing jobs is a dummy for not having the same main employer in the following year (in case of multiple employers, main employer is defined as the employer with whom regular earnings are highest). In Panel C, the sample is limited to workers with regular earnings in base year above the old cap. Percent with earnings (resp. gross earnings, net earnings) raise is a dummy for experiencing a nominal regular earnings (resp. gross earnings, net earnings) increase in the following year. 


\section{Annex I}

Questions in the Survey of Employers

- When you recruit a relatively young executive, do you know (or ask) which insurance regime $\mathrm{s} / \mathrm{he}$ is under?

- Are you aware that social contributions for high earners first insured in 1993 or later are higher, due to the fact that their upper earnings ceiling is higher (e.g. €5,280 vs. €2,315 in 2007)?

If yes, do you take this factor into consideration when you take decisions with respect to hiring, paying, promoting or firing employees?

More specifically, does the different social insurance regime make it more likely for you to:

- $\quad$ avoid recruitment of high-earning "new insurees"?

- $\quad$ offer lower remuneration to high-earning new insurees (as their labour costs may be higher) compared to older workers with similar skills?

- $\quad$ grant high-earning new insurees lower pay rises (to recoup the extra cost in terms of social contributions) compared to older workers with similar skills?

- make new insurees redundant ahead of older workers with similar skills?

If not, why should a profit-maximising firm not take this factor into consideration?

[let the interviewee respond spontaneously and then ask:]

Is it because the firm is concerned that discriminations on grounds of social insurance regime might:

- $\quad$ provoke new insurees to take legal action?

- harm morale in the firm?

- $\quad$ cause a reaction on the part of unions? 